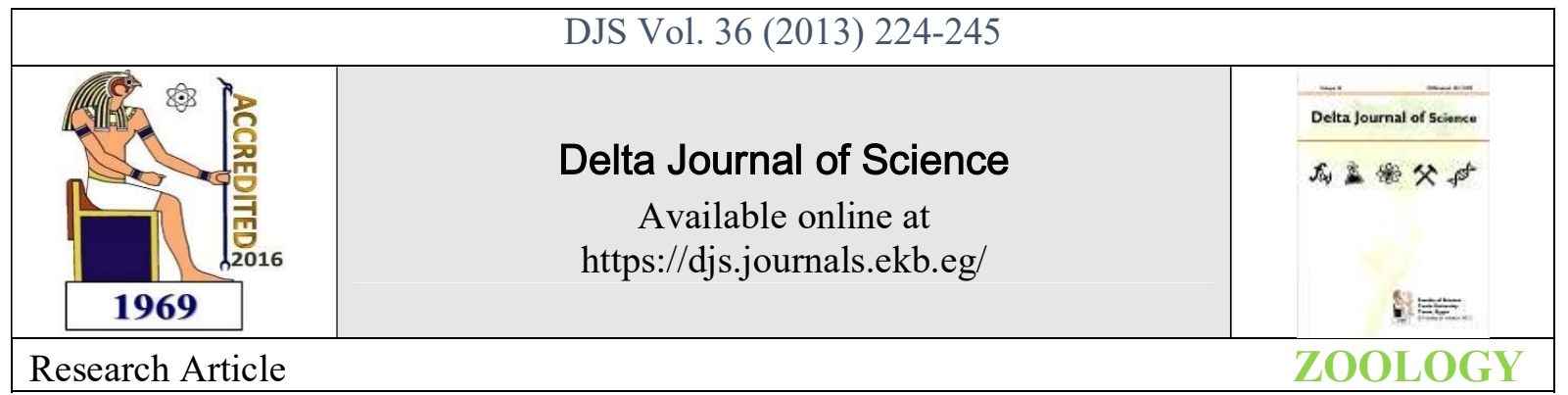

\title{
Abundance and distribution of soil microarthropods in solar impacted soil
}

\author{
Lamiaa A. Sharra and Ensaf A. El-Gayar \\ Zoology Department, Faculty of Science, Tanta University
}

\begin{abstract}
Petroleum hydrocarbons were intended to address risks to soil microarthropods and various other soil fauna that are considered to be important in maintaining a minimum level of soil ecological functioning. The study was carried out in cultivated soil exposed to petroleum hydrocarbon product PHC (solar) produced from a mixture station of Asphalt at Berma Village. Egypt. Another unpolluted soil adjacent to the polluted soil was chosen as control. The experiment was undertaken for four seasons.

This paper focuses on the effect of this product on the species richness, species abundance, and vertical distribution of soil microarthropods (mites,collembolans, and Mesostigmata). Extraction of organisms was carried out using the Berlese-Tullgren funnel. In the unpolluted and polluted habitats, there was an inverse relationship between mite/ collembolan abundance/density (except in the Mesostigmata )and soil depth; however, the correlations were not significant. In contrast, there was a significant direct correlation between mite abundance/density and depth in the polluted habitat, $(\mathrm{F}=29.11 ; \mathrm{df}=1.3 ; \mathrm{p}<0.05)$. In the unpolluted habitat, approximately all mites and $90 \%$ of collembolans were collected within the range 0.00 $10.0 \mathrm{~cm}$. In the habitat, polluted with petroleum hydrocarbon $(\mathrm{PHC})$ contamination, no mites were collected above a depth of $5.0 \mathrm{~cm}$ and $70 \%$ were found below $10.0 \mathrm{~cm}$. There were direct relationships between collembolan densities and soil depths in the two habitat-types (polluted and control) but the correlations were not significant $(\mathrm{F}=6.22 ; \mathrm{df}=1.3 ; \mathrm{p}>0.05)$. In the unpolluted habitat, approximately $90 \%$ of all collembolans were found above a depth of $10.0 \mathrm{~cm}$; this declined to $30 \%$ in the polluted soil. Mesostigmata and occupied lower layers below $5 \mathrm{~cm}$ in polluted and unpolluted soil.
\end{abstract}

Key words: microarthropods-vertical distribution hydrocarbon- species richness.

\section{INTRODUCTION}

Soil contamination typically arises from the rupture of underground storage tanks, application of pesticides, percolation of contaminated surface water to subsurface strata, oil and fuel dumping, leaching of wastes from landfills or direct discharge of industrial wastes to the soil. The most common chemicals involved are petroleum hydrocarbons, solvents, pesticides, and heavy metals. Petroleum hydrocarbons (PHCs) are complex mixtures of aliphatic, alicyclic and aromatic compounds (Miller \& Herman, 1997; Potter \& Simmons, 1998) plus constituents that contain N, S or $\mathrm{O}$ in addition to $\mathrm{H}$ and $\mathrm{C}$. PHCs may find their way into terrestrial ecosystems by surface spills or leaks from pipelines or storage tanks.

Soil microarthropods are ecologically important in terms of soil structure, nutrient cycling and as food for wide life. They are however sensitive to soil contaminants due to their intimate contact with consumption of contaminated soil. Soil microarthropod fauna are important indicator of reclamation activities in recovery soil habitat since they respond quickly to change in chemical and physical properties of habitat (Suncor and albian 2000).
Contamination of soll from petroleum hydrocarbons is classified into acute which occur in a short time period as spills from tanks or Pipes and chronic type which a release of over an extended period such as leakages from tanks or pipes of vehicle direct to the soil surface (Barnthouse and Brown, 1994).

There is no doubt that contamination of soils would affect the soil fauna thereby influencing decomposition, release of

nutrients as well as their availability for plant growth (Tadros and Varney 1983). Acari and collembolan are the two most important groups of micro arthropods in the soil and they account for $95 \%$ of the soil arthropod fauna (Seasted and Crosseley, 1984). Harsh soil condition prompt soil arthropods to move downward below $10 \mathrm{~cm}$ from soil surface (Seasted 1984; Setala et al. 1990 \& Iioba and Ekrakene 2008).

Simple physical or chemical determinations are limited in monitoring the effects of pollution because the total concentration measured in the individual can easily overestimate its biological significance. Other limitations include restriction of data to the moment of sampling and the 
methods do not take cognizance of the patchy distribution of chemicals in the environment; chemical analyses are time consuming, expensive and often limited to suspect compounds (Samuel et al. 2011). Biological monitoring aims to assess the significance of a pollutant for an organism in its habitat and other members of its community. Two basic approaches are used to measure the impact: the use of monitor and indicator species (Martin and Coughtrey, 1982). Monitor species are organisms whose ability to accumulate pollutants is used to assess the scale and distribution of the pollution insult. They are generally tolerant of the stress. In contrast, indicator species are sensitive to the pollutant and their presence or absence is taken to indicate a significant level of contamination (Beeby, 1993).

Among the acari, Oribatid mites are considered suitable indicators of soil systems; they have high diversity, densities and are sensitive to environmental changes (Behan-Pelletier, 1999 \& Paoletti et al., 2007). They are long-lived, iteroparous, have low fecundity and slow development rates (Norton, 1985 \& 1994). They have little capacity for rapid population growth and few are adapted for dispersal; they are therefore unable to easily escape environmental stress (BehanPelletier, 1999).Total abundance of order Acarina was negatively associated with chronic low- level of polycyclic aromatic hydrocarbon concentrations( Erstfeld and Snow, 1999). Collembolans are among the most abundant arthropods on earth with a long evolutionary history (Engel and Grimaldi, 2004). Most species consume fungi, in soil and leaf litter, they have radiated into many niches, from the littoral zone to mountain tops and are particularly abundant in epiphytes of tropical rainforests (Hopkin,1997). Collembolans are an integral part of soil ecosystems and are vulnerable to the effects of soil contamination. The abundance and diversity of Collembola have been widely used to assess the environmental impact of a range of pollutants on soils (Van Straalen and Lokke, 1997; Van Straalen and Van Leeuwen, 2002; Van Straalen, 2003, 2004). Little is known about PHC toxicity to plant and micro arthropods communities in forest soils as the majority of studies have excluded the complex interactions between combinations of chemicals, interacting communities and the soil environment that may exert synergistic, potentiative or antagonistic effects (Landis \& Yu, 1995; Evans \& Hedger, 2001; Koivula et al., 2004).Thus the present work aims to study the effects of solar pollution (Petroleum hydrocarbons) on community structure, densities, abundances and vertical distribution of soil micro arthropods.

\section{Materials and Methods}

\section{Study area and sampling:}

The present study was conducted in a cultivated soil (approximately $360 \mathrm{~m}^{2}$ ) adjacent to a mixture station of asphalt at Berma village for one year (from December 2009 to November 2010) in Egypt. The selected soil was frequently exposed to solar (effluent of petroleum products) due to the leaks from underground storage solar tank. Another cultivated soil adjacent to the polluted soil was chosen as control $\left(525 \mathrm{~m}^{2}\right)$. Both the two designated sites were all of the same soil type (clay) and had been cultivated with Onion, Wheat and Zea maize during the year of study. The polluted and unpolluted areas were each divided into $10 \times 6 \mathrm{~m}$ sub-plots to ensure total coverage during sampling. Soil samples (Six samples by sampling date) were taken seasonally from each sub-plot at three depths from the top surface layer to $5 \mathrm{~cm}, 5-$ $10 \mathrm{~cm}$ and from $10-15 \mathrm{~cm}$ with a split core sampler $(15 \mathrm{~cm}$ in depth and $10 \mathrm{~cm}$ diameter).. Each sample which was taken from each subplot was placed in a plastic bag, labeled and taken to the laboratory for analysis in a three- stage process (extraction, sorting and identification).Modified Berleses funnels extractor (as recommended by Bayoumi 1978 and AlAssiuty1981) was used for extracting soil microarthropods. Sorting of microarthropods was done under a binocular dissecting microscope. Keys (Krantz, 1978; Norton, 1990, and Woolly, 1990) were used for identification of micro arthropods.

\section{Measurements of parameters:}

The various parameters that were monitored and measured include organic matter contents, soil $\mathrm{pH}$, moisture content and soil temperature in both polluted and unpolluted soils according to Klute(1986) .Solar concentration (Total hydrocarbon content) in polluted soil was measured according to Iioba and Ekrakene (2008).

\section{Soil Total Hydrocarbon:}

The soil total hydrocarbon was determined according to Lioba \& Ekrakene (2008) using a spectrophotometer, pipette and $250 \mathrm{ml}$ separating glass funnel, mechanical shaker and nhexane A $5 \mathrm{~g}$ weight of soil sampled from within the upper $0-5$ $\mathrm{cm}$ from each site was dried and kept in bottle containers. To each bottle container was added $25 \mathrm{ml}$ of $\mathrm{n}$-hexane to extract the soil total hydrocarbon from the soil. These were placed on the mechanical shaker and shaken for 10 minutes to ensure thorough mixing and thereafter left to stand. A standard of nhexane was prepared and used to standardize the spectrophotometer before introducing: the THC from the soil into the spectrophotometer for the absorbance reading. The soil total hydrocarbon content (THC) concentration in part per million for each was then calculated as follows;

Soil total hydrocarbon content $(\mathrm{ppm})=$ Instrument Reading $(I R) \times$ Reciprocal of slope $\times 25 \mathrm{ml} / 5 \mathrm{~g}$ Where, Instrument reading (IR) was from the spectrophotometer. The reciprocal of slope was calculated for each based on spectrophotometer reading, Volume of extraction reagent was $25 \mathrm{ml}$, sampling periods. Weight of each soil sample used was $5 \mathrm{~g}$.

\section{Data analysis}

Microarthropod ( Acarina and Collembola) abundance and vertical distribution were evaluated .Analysis of variance was used to evaluate trends in the responses of these target organisms to Total hydrocarbon concentration (solar). Total counts of Oribatida and Collembola were made to allow comparison, using one-way ANOVA, between polluted and control treatment. Test of significance (T-test) was applied to the obtained data.

\section{RESULTS}

\section{A biotic soil conditions:}

Table 1 shows the physicochemical parameters of the soil. Differences in soil $\mathrm{pH}$ and organic matter content between the sampling dates were less obvious $(p>0.05$ T-test). The maximum amount of organic matter was measured in spring. Soil temperatures were higher in summer than for the other sampling dates in polluted and control soil. In accordance with the general trends observed in air temperature, the maximum $(28.7,28.2 \mathrm{C})$ and minimum $(12.5,12.0 \mathrm{C})$ soil temperatures were recorded in summer and winter, respectively.

The lowest soil moisture was observed in summer. In both polluted and control soils. But values showed no significant differences with the other months $((p>0.05)$. The maximum 
value of this parameter was obtained in winter and was higher than at the other sampling times $(p<0.05)$.

Analysis of total Hydrocarbon content of soil from control and polluted habitat, showed concentrations of 5.3 and 435.7 $\mathrm{mg} / \mathrm{kg}$, respectively.

\section{Species abundances:}

The obtained results revealed that, the Oribatid mites (Scheloribates laevigatus and Scheloribates latipes ) were the most abundant while Rhysotritia $a$. ardua and Scheloribates confundatus were the least abundant In both control and polluted habitat at all seasons (table 2 a,b,c,d ). Rhysotritia $a$. ardua was restricted to the control habitat during all studied seasons, while Oppia magnus was restricted to control habitat during winter. Scheloribates laevigatus, Scheloribates latipes, Scheloribates zaher Scheloribates confundatus and Galumna tarsipennata were collected from both control and polluted sites in winter and spring but their densities were higher in control than in polluted area. Scheloribates latipes and Scheloribates confundatus were abudant in summer in both polluted and control sites and restricted at depth $0-5 \mathrm{~cm}, 5-$ $10 \mathrm{~cm}$ in control habitat and at $10-15 \mathrm{~cm}$ in polluted habitat.

\section{Vertical distribution:}

In control habitat, most collected soil mites were found in samples from the surface soil layer $(0-5 \mathrm{~cm})$ (fig7,8). For Oribatid, Mesostigmata and Collembola; mean abundance in the $0-5 \mathrm{~cm}$ samples were significantly greater $(\mathrm{p}<0.05)$ than the abundance for other depths, which were not significantly different among themselves $(\mathrm{p}>0.05)$. Only Mesostigmata were found at lower depth $(5-10 \mathrm{~cm})$ in spring, but not during other seasons. There was direct relationship between soil depth and total mite and collembolan densities and the correlation was significant $(\mathrm{r}=0.93 ; \mathrm{f}=21.12 ; \mathrm{df}=1,3 ; \mathrm{p}<0.05)$. Similar patterns were observed in Mesostigmata and Collembola.

In control habitat; approximately $90 \%$ of all collected collembolans were collected above $10 \mathrm{~cm}$ level.

In polluted area; oribatid mites were abundant only in the 5$10 \mathrm{~cm}$ samples. They were dominated by Scheloribates laevigatus and Scheloribates latipes which occurred almost exclusively in the level of $5-10 \mathrm{~cm}$ in autmn and winter and in the level of $10-15 \mathrm{~cm}$ in spring and at $5-10 \mathrm{~cm}$ in autumn (table 2a, Fig.1). There was positive correlation between soil depth and densities of total mites $(\mathrm{r}=0.91 ; \mathrm{f}=25.11 ; \mathrm{df}=1,3 ; \mathrm{p}<0.05)$ (Fig.4). Approximately $70 \%$ of all oribatid mites in polluted area was collected at $10-15 \mathrm{~cm}$ level. There were inverse relationships between soil depth and collembolan densities in all seasons of the year. The correlations were significant $(\mathrm{f}=10.2 ; \mathrm{df}=1,3 ; \mathrm{p}<0.05)$ (Fig5).

Mesostigmata was essentially recorded in the $0-5 \mathrm{~cm}$ and 5 $10 \mathrm{~cm}$ strata all year round. They were more abundant in 5$10 \mathrm{~cm}$ stratum in spring and autumn (table2 Fig.6).

On the sampling dates (at all seasons) the mite populations were generally restricted to the upper level $(0-5 \mathrm{~cm})$ in control habitats while show corresponding increase in the lower layer $(5-10 \mathrm{~cm})$ in pollutes sites (Tables $2 \mathrm{a}, \mathrm{b}, \mathrm{c}, \mathrm{d})$.

\section{K- dominance curves:}

The rank abundance curve (Fig 9,10,11 and 12) showed different patterns for polluted and unpolluted biotopes, during the four seasons of study. At a depth $0-15 \mathrm{~cm}$, Where the most dominant species (Galumna tarsipennata and Scheloribates laevigatus ) during spring and autumn in the polluted habitat at a depth of $0-5 \mathrm{~cm}$ represent $38.4 \%$ and $50.6 \%$ of the total oribatid assemblage individuals in corresponding with (Scheloribates laevigatus and Scheloribates latipes) which represent (20\% and $21.7 \%$ ) of the total oribatid mites in reference habitat, respectively.

During summer, the most dominant species, Scheloribates laevigatus, showed the highest relative contribution $(50.6 \%)$ in polluted habitat in correspondence to $20.3 \%$ for Scheloribates latipes in reference habitat. However, in winter, no marked variation could be detected in the starting point of the k-dominance curve, however, in polluted habitat the start point was represented by Galumna tarsipennata in correspondence to Scheloribates laevigatus in reference habitat curve. It is interesting to clarify the important role of the second sequence species in determining the situation pattern of k-dominance curve such as during spring. In polluted habitat, Scheloribates latipes was the next abundant species raised the cumulative dominance value to about 36.5 $\%$ of the total oribatid mites. However, in the unpolluted habitat, both dominant species, Zygoribatula undulate represent $17.5 \%$ out of the total oribatid fauna. There is no significant difference between data at $5-10 \mathrm{~cm}$ depth (Fig 10) where the two curves behaved the same pattern in winter and autumn. A marked variation could be detected in the starting point of $\mathrm{K}$ - dominance curves in spring and summer in correspondence to control. The most dominant species (Scheloribates confundatus and Scheloribates latipes) during spring and summer in polluted habitat represent 34.5 and $32.6 \%$ of total oribatid assemblage individuals in corresponding with Scheloribates pallidulus and Zygoribatula aegyptiaca which represent 20.5 and $17.3 \%$ of the total Oribatid mites in reference habitat, respectively. At a depth of $10-15 \mathrm{~cm}$ (Fig11) Scheloribates latipes and Scheloribates laevigates represent 42 and $24.7 \%$ in polluted habitat in correspondence to Scheloribates confundatus and Scheloribates latipes which represent 30 and $36.1 \%$ of the total oribatid mites assemblages in control habitats.

In collembolla, the curves of polluted and control showed the same pattern in winter and spring. The polluted being the highest in summer where Isotomina orientalis represents 55\% of the total collembolan assemblage in correspondence to Isotomina thermophila which represents $39.9 \%$ in control curve.

\section{Discussion}

Petroleum hydrocarbons (PHC) polluted soils are characterized by lower values of soil moisture, compared to unpolluted soils (Trofimov \& Rozanova, 2003; Suleimanov et al., 2005).This is related to the spatial arrangement of hydrophobic components within soil organic matter (Roy \& McGill, 2000). The obtained results indicate that, microarthropods dwelling in control sites were more than those found in polluted sites with petroleum products (solar) because the animals may have moved below $10 \mathrm{~cm}$ into the soil in order to avoid unfavorable conditions. This agreed with the results obtained by Seasted (1980) and Setala et al. (1990) who stated that the presence of these contaminants affects soil microarthropods due to the contact with and consumption of contaminated soil. The contaminants immobilize nutrients and also affect the soil structure and lead to reduction of the soil oxygen level and soil water. This can lead to the death of some of these soil microarthropods (Stevenson 1994). Blakely et al. (2002) found that creosote impacted soil food webs and decomposition processes more by altering the habitat of microinvertebrates and their prey (i.e. fungi and bacteria) than via direct chemical toxicity. 
The increase of some oribatid species in winter and spring in polluted sites was probably due to rainfall decrease the concentration of hydrocarbon and also the activities of soil microarthropods as a result of death and decomposition by microbes. Mites may migrate vertically in the soil to escape adverse environmental conditions at the soil surface or to take advantage of seasonal availability of food and space (Luxton1981).

The concentration of soil mites in the $0-5 \mathrm{~cm}$ level indicates that the conditions are optimum at this level, and therefore migration to lower layers of the soil profile do not often occur. It was apparent that the effect of Hydrocarbon were more pronounced in the upper layers $(0-5 \mathrm{~cm})$ these effects were probably direct (lethal concentrations) or indirect (adversely affecting food sources, miroarthropod reproductive rate or soil quality). Seniczak et al.(1995) classified oribatid into three categories (quite susceptible, less susceptible and tolerant) based on their reaction to heavy metals. These categories may also be applicable to their responses to the hydrocarbon. The mainly predaceous mesostigmata were all adversely in the 0 $10 \mathrm{~cm}$ rang. The low numbers found below $10 \mathrm{~cm}$ were probably tolerant species (according to Seniczak et al.(1995).It is apparent that some species inhabiting depth below $10.0 \mathrm{~cm}$ may have adopted this strategy for the avoidance of unfavorable conditions( Bedanc et al. 2005). The death of some soil microarthropods is inevitable as a result of oxygen shortage and immobilization of nutrients (Stevenon, 1994). The absence of microarthropod in the area polluted with petroleum waste is due to depletion of oxygen because of increase in demand of oxygen by hydrocarbon degrading microbes for metabolic activities and this cause them to migrate even below the $10 \mathrm{~cm}$ depth in order to avoid harsh condition. There is thought to be some relationship between high diversity (species richness) and ecosystem health due to some degree of redundancy and the functional bases of fugal diversity as a results of soil pollution.

As regard to K-dominance curves. The concentration of dominance was higher in polluted habitat than in control thus the curve was deep in control but shallow in polluted plot. At impact plot, the K- dominance curve was shallower where it was dominated by only one oribatid species (Scheloribates laevigates) present in a large numbers on the contrary to control plot. The K- dominance curve showed an exponential pattern of deep start point where it was dominated by two species (Scheloribates confundatus and Scheloribates latipes) in autumn at adepth of $0-5 \mathrm{~cm}$.

\section{Conclusion}

From this study, the data presented indicate that the soil microarthropods were more or less evenly distributed in the study area occurs in substantial proportions at depths below or above those normally included in soil zoological studies.

In general, in the unpolluted area; population densities decreased gradually with increasing depth, Some taxa were distinctly more abundant under natural conditions of climate which would tend to favor the development of a mesofauna (Price 1973). However, the data suggest that the oily polluted area; may have a greater impact on population densities in the surface layers than on those in deeper soil. These organisms move downwards when they are disturbed by petroleum product in order to avoid these unfavorable conditions.

In fact, studies of Petroleum hydrocarbons contamination in cultivated soils are rare, as are the impacts on soil organisms and the intrinsic decomposition in these systems. The scientific basis for current remediation standards is based on information from experiments examining the toxicological impacts of Petroleum hydrocarbon chemicals on test organisms. More research in this area is needed. Future research is needed to determine how toxicity varies with type of pollutant, mixtures of pollutants, extent of pollution, and the general condition of the ecosystem prior to chemical disturbance.

\section{References}

Al-Assiuty,A.I.(1981):Ecological and experimental studies on the oribatid mite fauna of Egypt. Ph.D.Thesis,Fac. Sci. Tanta Univ. Egypt.432 pp.

Barnthouse, L.W. and J. Brown, ( 1994): Conceptual model on oil contamination of Soil. United States, Biology and Fertility of Soil., 46: 249-254.

Bayoumi,B.M.(1978):Comparative ecological and taxonomical studies on the oribatid fauna (Acarina) in some deciduous forest.Ph.D.Thesis, Hung. Acad.Sci. Budapest. 161 pp.

Bedano, J.C., Cantu, M.P.and Doucet, M.E. (2005): Abundance of soil mites (Arachnida: Acari) in a natural soil of central Argentina. - Zoological Studies 44(4): 505-512.

Beeby A (1993): Applying Ecology. Chapman \& Hall, London, p. 441.

Behan-Pelletier, V.M. (1999): Oribatid mite biodiversity in agro- ecosystems and environment: role for bioindication. Agriculture, Ecosystems and Environment. 74: 411-423.

Engel MS, Grimaldi D (2004): New light shed on the oldest insect. Nature, 427: 627- 630.

EVANS, C. S. and HEDGER, J. N. (2001): Degradation of plant cell wall polymers. In Fungi in bioremediation (ed. G. M. Gadd), pp. 1-26. British Mycological Society, Cambridge University Press, UK.

Hopkins S.P. (1997): Biology of the springtails (Insecta: Collembola). Oxford University Press, Oxford.

Iloba1B.N. and Ekrakene, T.(2008): Soil microarthropods recovery rates from $0-5 \mathrm{~cm}$ depth in 5 Months Period Following endosulfan organochlorine pesticide treatment in designated plots in Benin city Nigeria. Academic Journal of Entomology 1 (2): 36-44.

Klute,A. (1986): Methods of soil analysis, (Part1) Amer. Soc. Agronomy, Inc Soil Sci.Amer., Inc.( $3^{\text {rd }}$ edition), Madison, Wisconsin,USA.

Koivula, T. T., Salkinoja -Salonen, M., Peltola, R. and Romantschuk, M. (2004): Pyrene degradation in forest humus microcosms with or without pine and its mycorrhizal fungus. Journal of Environmental Quality 33, 45-53.

Krantz, G.W. (1978): A Manual of Acarology. Oregon 173 State University Book Stores Inc. Corvallis Louvainla-Neuve., 247-252.

Landis, W. G. and Yu, M.-H. (1995): Introduction to environmental toxicology: Impacts of chemicals upon 
ecological systems. Lewis Publishers, CRC Press, Boca Raton, Florida.

Luxton, M. (1981): studies on the oribatid mites of a Danish Beech wood soil part V. Vertical distribution. - Pedobiologia 21: 365-386.

Martin MH, Coughtrey PJ (1982): Biological monitoring of heavy metal pollution. Pollution Monitoring Series Ad. (Mellanby K. ed.). Applied science publishers Ltd. Londan and New York,p.475.

Mchael Hogan,Leda patmore, Gary latshaw and Harry seidman (1973): Computer modeling of pesticide transport in soil for five instrumented watersheds, prepared for the U.S. Environmental protection agency Southeast Water laboratory, Athens, Ga, by ESL Inc., Sunnyvale, California.

Miller, R. M. and Herman, D. C. (1997): Biotransformation of organic compounds in soils: remediation and ecotoxicological implications. In Soil Ecotoxicology (eds. J.

Tarradellas, G. Bitton and D. Rossel), pp. 53-84. Lewis Publishers, CRC Press Inc.,New York.

Norton RA (1985): Aspects of the biology and systematics of soil arachnids, particularly saprophygous and mycophagous mites. Quaestiones Entomologicae, 21: 523 - 541.

Norton, R.A (1990): Acarina: Oribatida. In Dindal, D.L.(Ed.) Soil Biology Guide. John Wiley, New York, pp 779-803.

Norton, R.A.and Behan-Pelletier, V.M. (1991): Calcium carbonate and calcium oxalate as cuticular hardening agents in oribatid mites (Acari: Oribatida). - Canadian Journal Of Zoology 69(6): 1504-1511.

Norton, R.A. (1994): Evolutionary aspects of oribatid mites life histories and Consequences for the origin of the Astigmata. - In: M.A. Houck (Ed.), Mites: Ecological and Evolutionary Analyses of Life-History Patterns, Chapman \& Hall, New York, pp. 99-135.

Paoletti MG, Osler GHR, Kinnear A, Black DG, Thomson LJ, Tsitsilas A, Sharley D, Judd S, Neville P and D'Inca A (2007): Detritivores as indicators of landscape and soil degradation. Australian J. Exper. Agric., 47: 412 - 423.

Potter, C. L. and Simmons, K. E. (1998): Composition of petroleum mixtures. volume 2, total hydrocarbon criteria working group series. Amherst Scientific Publishers, Amherst, Massachusetts.

Samuel Okiwelu1, Tambeke Gbarakoro1, Chris O. Umeozor1, Adetola and Badejo M (2012): Microarthropods in a Secondary Rainforest, Rivers State, Nigeria - Resources and Environment, 2(2): 14-19 DOI.

Seasted, T.R. (1984): The role of microathropods in decomposition and mineralization process. Ann. Rev Entomol., 29: 25-46

Seasted, T.R. and Crosseley, D.A. Jr, (1984): The influence of arthropod on ecosystems. Bioscience 34: 157-161.

Setala, H., Martikainen, E., Tyynisma, M. and Hunta, V. (1990): Effects of soil fauna on leaching of nitrogen and phosporus from experimental systems stimulating coniferous forest floor. Biology and fertility of soil., 10: 170-17.
Seniczak, S., Dabrowski, J.and Dlugosz, J.( 1995): Effect of copper smelting air pollution on the mites (Acari) associated with young scots pine forests polluted by a copper smelting works at Giogow, Poland. I. arboreal mites. water, air, and soil pollution. 94(3-4): 71-84.

Stevenson, F.J. (1994): Humus chemistry genesis, composition, reactions: Wiley Interscience. New 9: 25-46.

Suncor, E. and S. Albian,( 2000): A Research in soil and vegetation study in oil sands, Northern Alberta.

Tadros, M.S. and E.A. Varney (1983): The interaction between soil arthropods and soil Fungal in Woodland and Field Soils. In: Lebrum, P.H., Andre, H.M., Demedst, A., Gregoirie -Wibo, C. and Wauthy, G. (eds) Proceedings VIII International Soil Zoology Colloquim, Ottigness -LouvainlaNeuve.,247-252

VanStraalen NM (2003). Ecotoxicology becomes stress ecology. Environ. Sci. Technol., 37(17): 324A - 330A.

VanStraalen NM (2004). The use of soil invertebrates in ecological surveys of contaminated soils. In: Vital Soil, Function, Value and Properties (eds. P. Doelman and H.J.P. Eijsackers). Elsevier, Amsterdam, pp. 159-195.

VanStraalen NM, Lokke H (1997). Ecological approaches in soil ecotoxicology. In: Ecological Risk Assessment of Contaminants in Soil (eds NM Van Straalen and H Lokke). Chapman and Hall, London, pp. 3 - 21.

VanStraalen NM and VanLeeuwen CJ (2002). European history of species sensitivity distributions. In: Species Sensitivity Distributions in Ecotoxicology (eds. L. Posthuma, G. W. Suter II \& T. P. Traas). Lewis Publishers, Boca Raton, pp. 19-34.

Woolley T. A. (1990) Acarology: mites and human welfare. New York. John Willey. 463pp

Zaitsev A.S.and Van Straalen N.M. (2001) Species diversity and metal accumulation in oribatid mites (Acari, Oribatida) of forests affected by a metallurgical plant. Pedobiologia. 45(5): 467-479. 
Table(1) Physicochemical properties (mean \pm SE) of the top $15 \mathrm{~cm}$ of polluted(P) and control (C)soils.

\begin{tabular}{|c|c|c|c|c|c|c|c|c|}
\hline Seasons & \multicolumn{2}{|c|}{ Summer } & \multicolumn{2}{|c|}{ autumn } & \multicolumn{2}{|c|}{ winter } & \multicolumn{2}{|c|}{ spring } \\
\hline & $\mathrm{P}$ & $\mathrm{C}$ & $\mathrm{P}$ & $\mathrm{C}$ & $\mathrm{P}$ & $\mathrm{C}$ & $\mathrm{P}$ & $\mathrm{C}$ \\
\hline $\mathrm{OMC}(\%)$ & $3.3 \pm 0.55$ & $3.5 \pm 0.75$ & $2.9 \pm 0.88$ & $3.1 \pm 0.9$ & $3.2 \pm 0.3$ & $3.7 \pm 1.2$ & $4.2 \pm 1.8$ & $4.7 \pm 0.27$ \\
\hline $\mathrm{pH}$ & $7.7 \pm 0.1$ & $8.37 \pm 0.08$ & $7.85 \pm 0.3$ & $8.15 \pm 0.5$ & $7.78 \pm 0.2$ & $8.35 \pm 0.4$ & $7.76 \pm 0.6$ & $8.15 \pm 0.4$ \\
\hline Moisture (\%) & $21.13 \pm 1.3$ & $22.45 \pm 0.07$ & $24.17 \pm 1.1$ & $24.52 \pm 0.6$ & $24.75 \pm 0.9$ & $25.26 \pm 1.2$ & $22.12 \pm 0.3$ & $23.34 \pm 1.1$ \\
\hline Air temperature & $34.6 \pm 0.73$ & $34.6 \pm 0.73$ & $26.8 \pm 0.84$ & $26.8 \pm 0.84$ & $14.2 \pm 0.77$ & $14.2 \pm 0.77$ & $23.6 \pm 0.8$ & $23.6 \pm 0.8$ \\
\hline Soil temperature & $28.7 \pm 1.4$ & $28.02 \pm 1.14$ & $22.4 \pm 0.71$ & $21.9 \pm 0.55$ & $12.5 \pm 0.89$ & $12.0 \pm 0.83$ & $20.7 \pm 0.83$ & $19.7 \pm 1.2$ \\
\hline
\end{tabular}

Where OMC: organic matter content

Table (2a): Species richness and densities of mites (mean $\pm \mathrm{SE}$ ) at different depths from polluted and control habitats (in winter).

\begin{tabular}{|c|c|c|c|c|c|c|c|c|}
\hline \multirow{2}{*}{$\begin{array}{c}\text { Depth } \\
\text { Habitat }\end{array}$} & \multicolumn{2}{|c|}{$0-5 \mathrm{~cm}$} & \multicolumn{2}{|c|}{$5-10 \mathrm{~cm}$} & \multicolumn{2}{|c|}{$10-15 \mathrm{~cm}$} & \multicolumn{2}{|c|}{ total } \\
\hline & $\mathrm{P}$ & $\mathrm{C}$ & $\mathrm{P}$ & $\mathrm{C}$ & $\mathrm{P}$ & $\mathrm{C}$ & $\mathrm{P}$ & $\mathrm{C}$ \\
\hline \multicolumn{9}{|l|}{ Oribatid species } \\
\hline 1- Scheloribates laevigatus & $7.8 \pm 1.2$ & $100 \pm 4.2$ & $30 \pm 4.2$ & $16.4 \pm 2.1$ & $7.4 \pm 0.8$ & $2 \pm 0.5$ & 45.2 & 118.4 \\
\hline 2- Scheloribates latipes & $13.2 \pm 0.5$ & $59.2 \pm 0.6$ & $18.4 \pm 2.3$ & $12.2 \pm 1.2$ & $23.6 \pm 2.5$ & $6 \pm 0.6$ & 55.2 & 77.4 \\
\hline 3-Scheloribates zaheri & $4.2 \pm 0.3$ & $21.4 \pm 2.2$ & $2.6 \pm 0.1$ & $12.6 \pm 1.1$ & 0 & 0 & 6.8 & 34 \\
\hline 4-Scheloribates confundatus & $5.4 \pm 0.3$ & $85.2 \pm 3.5$ & $8.2 \pm 1.2$ & $20.2 \pm 2.6$ & $8 \pm 0.3$ & $3 \pm 3.5$ & 21.6 & 108.4 \\
\hline 5-Scheloribates pallidulus & 0 & 0 & 0 & 0 & 0 & 0 & 0 & 0 \\
\hline 6-Xylobates lophotrichus & 0 & 0 & 0 & 0 & 0 & 0 & 0 & 0 \\
\hline 7- Rhysotritia a. ardua & 0 & $5.8 \pm 0.6$ & 0 & $10.4 \pm 1.2$ & 0 & $3.2 \pm 0.1$ & 0 & 19.4 \\
\hline 8- Lamellobates h.aegypticus & 0 & 0 & 0 & 0 & 0 & 0 & 0 & 0 \\
\hline 9- Oppia magnus & 0 & $70 \pm 3.6$ & 0 & 0 & 0 & 0 & 0 & 70 \\
\hline 10- Zygoribatula aegyptiaca & 0 & 0 & 0 & 0 & 0 & 0 & 0 & 0 \\
\hline 11- Zygoribatula undulata & 0 & 0 & 0 & 0 & 0 & 0 & 0 & 0 \\
\hline 12- Galumna tarsipennata & $16.8 \pm 0.8$ & $35 \pm 1.8$ & $16.2 \pm 1.4$ & $30 \pm 1.8$ & $1.4 \pm 0.2$ & $5.2 \pm 0.7$ & 34.4 & 70.2 \\
\hline Density / sample & 47.4 & 376.6 & 75.4 & 101.8 & 40.4 & 19.4 & & \\
\hline \multicolumn{9}{|l|}{ Mesostigmata } \\
\hline 1- Urobovella krantz & $8.4 \pm 1.2$ & $25.2 \pm 2.1$ & $8.4 \pm 0.7$ & $10 \pm 0.4$ & 0 & 0 & 16.8 & 35.2 \\
\hline 2- Phytosieus sp. & 0 & $7.4 \pm 0.7$ & 0 & $2.2 \pm 0.05$ & 0 & 0 & 0 & 9.6 \\
\hline
\end{tabular}




\begin{tabular}{|l|c|c|c|c|c|c|c|c|}
\hline 3- Parasitus $s p$. & $12.2 \pm 2.3$ & $15.4 \pm 2.1$ & $8.2 \pm 0.6$ & $7.2 \pm 0.4$ & 0 & 0 & 20.4 & 22.6 \\
\hline 4- Rhodacaris $s p$. & 0 & $18.2 \pm 0.9$ & 0 & $9.4 \pm 0.3$ & 0 & 0 & 0 & 27.6 \\
\hline Density / sample & 20.6 & 66.2 & 16.6 & 28.8 & 0 & 0 & & \\
\hline
\end{tabular}

Table (2 b). Species richness and densities of mites (mean \pm SE) at different depths from polluted and control habitats (in spring).

\begin{tabular}{|c|c|c|c|c|c|c|c|c|}
\hline Depth & \multicolumn{2}{|c|}{$0-5 \mathrm{~cm}$} & \multicolumn{2}{|c|}{$5-10 \mathrm{~cm}$} & \multicolumn{2}{|c|}{$10-15 \mathrm{~cm}$} & \multicolumn{2}{|c|}{ total } \\
\hline Habitat & $\mathbf{P}$ & $\mathbf{C}$ & $\mathbf{P}$ & $\mathrm{C}$ & $\mathbf{P}$ & $\mathrm{C}$ & $\mathbf{P}$ & $\mathrm{C}$ \\
\hline Oribatid species & & & & & & & & \\
\hline 1- Scheloribates laevigatus & $5.2 \pm 0.65$ & $115.2 \pm 3.2$ & $10 \pm 0.8$ & $11.2 \pm 0.9$ & $30 \pm 3.6$ & $4.6 \pm 0.7$ & 45.2 & 131 \\
\hline 2- Scheloribates latipes & $15.2 \pm 0.8$ & $80 \pm 1.3$ & $13.4 \pm 1.2$ & $15.4 \pm 1.4$ & $40 \pm 4.3$ & $5.2 \pm 0.4$ & 68.6 & 100.6 \\
\hline 3-Scheloribates zaheri & 0 & $7.4 \pm 0.4$ & 0 & $7.2 \pm 0.6$ & 0 & $3.4 \pm 0.1$ & 0 & 18 \\
\hline $\begin{array}{l}\text { 4- Scheloribates } \\
\text { confundatus }\end{array}$ & $5.2 \pm 0.1$ & $56.2 \pm 2.6$ & $15.2 \pm 2.1$ & $28.2 \pm 2.9$ & $15.2 \pm 3.2$ & $6.6 \pm 1.2$ & 35.6 & 91 \\
\hline 5-Scheloribates pallidulus & 0 & $70 \pm 2.6$ & 0 & $30 \pm 1.8$ & 0 & 0 & 0 & 100 \\
\hline 6-Xylobates lophotrichus & 0 & $75.4 \pm 4.6$ & 0 & $25.2 \pm 2.3$ & 0 & 0 & 0 & 100.6 \\
\hline 7- Rhysotritia a. ardua & 0 & $8.4 \pm 0.1$ & 0 & $9.2 \pm 0.2$ & 0 & 2.2 & 0 & 19.8 \\
\hline $\begin{array}{l}\text { 8- Lamellobates } h \text {. } \\
\text { aegypticus }\end{array}$ & 0 & 0 & 0 & 0 & 0 & 0 & 0 & 0 \\
\hline 9- Oppia magnus & 0 & $15.2 \pm 1.3$ & 0 & $10 \pm 0.9$ & 0 & 0 & 0 & 25.2 \\
\hline 10- Zygoribatula aegyptiaca & 0 & $20 \pm 2.1$ & 0 & 0 & 0 & 0 & 0 & 20 \\
\hline 11- Zygoribatula undulata & 0 & $100 \pm 3.6$ & 0 & 0 & 0 & 0 & 0 & 100 \\
\hline 12- Galumna tarsipennata & $16 \pm 0.5$ & $25.2 \pm 1.6$ & $5.4 \pm 0.3$ & $20 \pm 2.3$ & $10 \pm 1.4$ & 0 & 15.4 & 45.2 \\
\hline Density / sample & 41.6 & 573 & 44 & 146.4 & 95.2 & 22 & & \\
\hline Mesostigmata & & & & & & & & \\
\hline 1- Urobovella krantz & $8 \pm 0.9$ & $10 \pm 1.2$ & $9.2 \pm 1$ & $12.4 \pm 2.3$ & 0 & 0 & 17.2 & 22.4 \\
\hline 2-Phytosieus $s p$ & $5.2 \pm 0.3$ & $7.4 \pm 1.5$ & $8.2 \pm 1.2$ & $13.2 \pm 1.4$ & 0 & 0 & 13.4 & 20.6 \\
\hline 3-Parasitus $s p$ & $5.2 \pm 0.1$ & $5.4 \pm 0.4$ & $8.2 \pm 0.2$ & $8.4 \pm 0.4$ & 0 & 0 & 13.4 & 13.8 \\
\hline 4- Rhodacaris $s p$ & 0 & $20 \pm 1$ & 0 & $17.4 \pm 0.8$ & 0 & 0 & 0 & 37.4 \\
\hline Density / sample & 20.4 & 42.8 & 25.6 & 51.4 & 0 & 0 & & \\
\hline
\end{tabular}


Table (2c). Species richness and densities of mites (mean \pm SE) at different depths from polluted and control habitats (in summer).

\begin{tabular}{|l|c|c|c|c|c|c|c|c|}
\hline \multicolumn{1}{|c|}{ Depth } & \multicolumn{2}{|c|}{$\mathbf{0 - 5} \mathbf{~ c m}$} & \multicolumn{2}{c|}{$\mathbf{5}-\mathbf{1 0} \mathbf{~ c m}$} & \multicolumn{2}{c|}{$\mathbf{1 0}-\mathbf{1 5} \mathbf{~ c m}$} & \multicolumn{2}{|c|}{ total } \\
\hline Habitat & $\mathbf{P}$ & $\mathbf{C}$ & $\mathbf{P}$ & $\mathbf{C}$ & $\mathbf{P}$ & $\mathbf{C}$ & $\mathbf{P}$ & $\mathbf{C}$ \\
\hline Oribatid species & & & & & & & & \\
\hline 1- Scheloribates laevigatus & $16.4 \pm 0.9$ & $108.2 \pm 1.2$ & $19.4 \pm 2.3$ & $16.2 \pm 2.3$ & $11 \pm 1.3$ & $16.8 \pm 2.1$ & 46.8 & 141.2 \\
\hline 2- Scheloribates latipes & $4 \pm 0.5$ & $50 \pm 2.1$ & $20 \pm 1.5$ & $30 \pm 2.5$ & $30 \pm 2.6$ & $9.4 \pm 0.9$ & 54 & 89.4 \\
\hline 3- Scheloribates zaheri & 0 & $3.4 \pm 0.2$ & 0 & $3.6 \pm 0.3$ & 0 & 0 & 0 & 7 \\
\hline 4- Scheloribates confundatus & $6.4 \pm 0.6$ & $100 \pm 3.3$ & $20 \pm 2.3$ & $18.6 \pm 1.5$ & $10 \pm 0.9$ & $2 \pm 0.2$ & 36.4 & 120.6 \\
\hline 5- Scheloribates pallidulus & 0 & 0 & 0 & 0 & 0 & 0 & 0 & 0 \\
\hline 6-Xylobates lophotrichus & $3.6 \pm 0.1$ & $30 \pm 3.2$ & 0 & $10 \pm 1.1$ & 0 & $3.2 \pm 0.5$ & 3.6 & 43.2 \\
\hline 7- Rhysotritia a. ardua & 0 & $5.2 \pm 0.3$ & 0 & $1.4 \pm 0.2$ & 0 & 0 & 0 & 6.6 \\
\hline 8- Lamellobates h. aegypticus & 0 & $46.4 \pm 2.1$ & 0 & $23.6 \pm 1.4$ & 0 & 0 & 0 & 70 \\
\hline 9- Oppia magnus & 0 & 0 & 0 & 0 & 0 & 0 & 0 & 0 \\
\hline 10- Zygoribatula aegyptiaca & 0 & $65.2 \pm 5.4$ & 0 & $30 \pm 4.1$ & 0 & $2.4 \pm 0.2$ & 0 & 97.6 \\
\hline 11- Zygoribatula undulata & 0 & $100 \pm 5.6$ & 0 & $20 \pm 3.2$ & 0 & 0 & 0 & 120 \\
\hline 12- Galumna tarsipennata & $2 \pm 0.3$ & $25.2 \pm 1.2$ & $2 \pm 0.1$ & $20 \pm 1.7$ & $2 \pm 0.5$ & $3 \pm 0.3$ & 6 & 48.2 \\
\hline Density / sample & 32.4 & 533.6 & 61.4 & 173.4 & 53 & 36.8 & & \\
\hline Mesostigmata & & & & & & & & \\
\hline 1- Urobovella krantz & $16.2 \pm 1.1$ & $18.4 \pm 0.9$ & $10 \pm 0.3$ & $15.6 \pm 1.6$ & 0 & 0 & 26.2 & 34 \\
\hline 2- Phytosieus sp & 0 & 0 & 0 & 0 & 0 & 0 & 0 & 0 \\
\hline 3- Parasitus sp & 0 & 0 & 0 & 0 & 0 & 0 & 0 & 0 \\
\hline 4- Rhodacaris sp & 0 & $10 \pm 0.5$ & 0 & $5.2 \pm 0.4$ & 0 & 0 & 0 & 15.2 \\
\hline Density / sample & 16.2 & 28.4 & 10 & 20.8 & 0 & 0 & & \\
\hline
\end{tabular}


Table (2 d). Species richness and densities of mites (mean \pm SE) at different depths from polluted and control habitats (in autumn).

\begin{tabular}{|c|c|c|c|c|c|c|c|c|}
\hline Depth & \multicolumn{2}{|c|}{$0-5 \mathrm{~cm}$} & \multicolumn{2}{|c|}{$5-10 \mathrm{~cm}$} & \multicolumn{2}{|c|}{$10-15 \mathrm{~cm}$} & \multicolumn{2}{|c|}{ total } \\
\hline Habitat & $\mathbf{P}$ & $\mathrm{C}$ & $\mathbf{P}$ & $\mathbf{C}$ & $\mathbf{P}$ & $\mathbf{C}$ & $\mathbf{P}$ & $\mathbf{C}$ \\
\hline \multicolumn{9}{|l|}{ Oribatid species } \\
\hline 1- Scheloribates laevigatus & $30 \pm 2.3$ & $85.2 \pm 1.1$ & $74 \pm 5.2$ & $10 \pm 1.2$ & $11.6 \pm 1.9$ & $5 \pm 2$ & 115.6 & 100.2 \\
\hline 2- Scheloribates latipes & $15.2 \pm 0.6$ & $40 \pm 1.1$ & $30 \pm 3.5$ & $4 \pm 0.3$ & $10 \pm 0.8$ & $16.4 \pm 1.6$ & 55.2 & 60.4 \\
\hline 3-Scheloribates zaheri & 0 & 0 & 0 & 0 & 0 & 0 & 0 & 0 \\
\hline 4- Scheloribates confundatus & $7 \pm 0.1$ & $80 \pm 2.1$ & $10 \pm 0.9$ & $19.4 \pm 2.6$ & $10 \pm 2$ & $5.2 \pm 1.3$ & 27 & 104.6 \\
\hline 5- Scheloribates pallidulus & 0 & 0 & 0 & 0 & 0 & 0 & 0 & 0 \\
\hline 6-Xylobates lophotrichus & 0 & $50 \pm 4.1$ & $10 \pm 1.2$ & $10 \pm 1$ & $5.4 \pm 0.6$ & $8.2 \pm 0.7$ & 15.4 & 68.2 \\
\hline 7- Rhysotritia a. ardua & 0 & $12.2 \pm 0.7$ & 0 & $10 \pm 0.8$ & 0 & $3.4 \pm 0.3$ & 0 & 25.6 \\
\hline 8- Lamellobates h. aegypticus & 0 & $34.2 \pm 2.3$ & 0 & $26.2 \pm 2.4$ & 0 & 0 & 0 & 60.4 \\
\hline 9- Oppia magnus & 0 & 0 & 0 & 0 & 0 & 0 & 0 & 0 \\
\hline 10- Zygoribatula aegyptiaca & 0 & 0 & 0 & 0 & 0 & 0 & 0 & 0 \\
\hline 11- Zygoribatula undulata & $3.6 \pm 0.4$ & $80 \pm 2.5$ & $3.6 \pm 0.5$ & $10 \pm 0.5$ & 0 & $3.2 \pm 0.3$ & 7.2 & 93.2 \\
\hline 12- Galumna tarsipennata & $3.4 \pm 0.1$ & $10 \pm 1.3$ & $5.4 \pm 0.8$ & $20 \pm 2.4$ & $10 \pm 1.4$ & $4 \pm 0.6$ & 18.8 & 34 \\
\hline Density / sample & 59.2 & 391.6 & 133 & 109.6 & 47 & 45.4 & & \\
\hline \multicolumn{9}{|l|}{ Mesostigmata } \\
\hline 1- Urobovella krantz & $3.4 \pm 0.4$ & $5.2 \pm 0.7$ & $5.4 \pm 0.3$ & $6.2 \pm 0.6$ & 0 & 0 & 8.8 & 11.4 \\
\hline 2- Phytosieus sp & 0 & 0 & 0 & 0 & 0 & 0 & 0 & 0 \\
\hline 3-Parasitus sp & $3.2 \pm$ & $3.4 \pm$ & 0 & 0 & 0 & 0 & 3.2 & 3.4 \\
\hline 4- Rhodacaris sp & $2.6 \pm 0.3$ & $8.2 \pm 0.6$ & $5.2 \pm 0.4$ & $12.2 \pm 1.2$ & 0 & 0 & 7.8 & 20.4 \\
\hline Density / sample & 9.2 & 16.8 & 10.6 & 18.4 & 0 & 0 & & \\
\hline
\end{tabular}

Table (3a). Species richness and densities of collembolan (mean \pm SE) at different depths from polluted and control habitats (in winter).

\begin{tabular}{|c|c|c|c|c|c|c|c|c|}
\hline Depth & \multicolumn{2}{|c|}{$\mathbf{0}-\mathbf{5}$} & \multicolumn{2}{c|}{$\mathbf{5}-\mathbf{1 0} \mathbf{c m}$} & \multicolumn{1}{c|}{$\mathbf{1 0} \mathbf{~ c m}$} & \multicolumn{2}{c|}{ total } \\
\hline Habitat & $\mathbf{P}$ & $\mathbf{C}$ & $\mathbf{P}$ & $\mathbf{C}$ & $\mathbf{P}$ & $\mathbf{C}$ & $\mathbf{P}$ & $\mathbf{C}$ \\
\hline Collembola & & & & & & & & \\
\hline 1- Thermobia aegyptiaca & $1.6 \pm 0.01$ & $5.2 \pm 1.2$ & $2.4 \pm 0.05$ & $10.8 \pm 1.4$ & 0 & 0 & 4 & 16 \\
\hline 2-Isotomina thermophila & 0 & $7.4 \pm 1.3$ & 0 & 0 & 0 & 0 & 0 & 7.4 \\
\hline 3- Isotomina orientalis & $3.2 \pm 0.4$ & $7.8 \pm 0.9$ & 0 & 0 & 0 & 0 & 3.2 & 7.8 \\
\hline
\end{tabular}




\begin{tabular}{|l|c|c|c|c|c|c|c|c|}
\hline 4- Isotoma viridis & $6.6 \pm 0.6$ & $10.8 \pm 1.8$ & 0 & 0 & 0 & 0 & 6.6 & 10.8 \\
\hline 5- Hypogastrura denticulata & 0 & $8.4 \pm 1.4$ & $5.6 \pm 0.7$ & $11.2 \pm 1.6$ & 0 & $3.2 \pm 0.4$ & 5.6 & 22.8 \\
\hline 6 -Priosotoma minuta & 0 & $5.2 \pm 0.5$ & 0 & $5.8 \pm 0.8$ & 0 & 0 & 0 & 11 \\
\hline 7- Entomobrya dollfusi & $6.8 \pm 1.2$ & $20.4 \pm 2.6$ & 0 & 0 & 0 & 0 & 6.8 & 20.4 \\
\hline Density / sample & 18.2 & 65.2 & 8 & 27.8 & 0 & 3.2 & & \\
\hline
\end{tabular}

Table (3b). Species richness and densities of collembola (mean \pm SE) at different depths from polluted and control habitats (in spring).

\begin{tabular}{|l|c|c|c|c|c|c|c|c|}
\hline \multicolumn{1}{|c|}{ Depth } & \multicolumn{2}{|c|}{$\mathbf{0}-\mathbf{c m}$} & \multicolumn{2}{c|}{$\mathbf{5 - 1 0} \mathbf{c m}$} & \multicolumn{1}{c|}{$\mathbf{1 0}-\mathbf{1 5} \mathbf{~ c m}$} & \multicolumn{2}{c|}{ total } \\
\hline Habitat & $\mathbf{P}$ & $\mathbf{C}$ & $\mathbf{P}$ & $\mathbf{C}$ & $\mathbf{P}$ & $\mathbf{C}$ & $\mathbf{P}$ & $\mathbf{C}$ \\
\hline Collembola & & & & & & & & \\
\hline 1- Thermobia aegyptiaca & 0 & $1.2 \pm 0.03$ & $2.4 \pm 0.3$ & $15.2 \pm 1.6$ & 0 & 0 & 2.4 & 16.4 \\
\hline 2-Isotomina thermophila & 0 & $15.8 \pm 2$ & 0 & 0 & 0 & 0 & 0 & 15.8 \\
\hline 3- Isotomina orientalis & $5.2 \pm 0.7$ & $18.2 \pm 1.9$ & 0 & 0 & 0 & 0 & 5.2 & 18.2 \\
\hline 4- Isotoma viridis & $10 \pm 0.7$ & $17.6 \pm 1.9$ & 0 & 0 & 0 & 0 & 10 & 17.6 \\
\hline 5- Hypogastrura denticulata & 0 & $4.4 \pm 0.4$ & $2.2 \pm 0.2$ & $14.6 \pm 1.6$ & 0 & 0 & 2.2 & 19 \\
\hline 6 -Priosotoma minuta & 0 & 0 & 0 & $9.4 \pm 1.2$ & 0 & 0 & 0 & 9.4 \\
\hline 7- Entomobrya dollfusi & $10.6 \pm 0.9$ & $49.2 \pm 3.2$ & 0 & 0 & 0 & 0 & 10.6 & 49.2 \\
\hline Density / sample & 25.8 & 106.4 & 4.6 & 39.2 & 0 & 0 & & \\
\hline
\end{tabular}

Table (3c). Species richness and densities of collembola (mean \pm SE) at different depths from polluted and control habitats (in summer).

\begin{tabular}{|l|c|c|c|c|c|c|c|c|}
\hline \multicolumn{1}{|c|}{ Depth } & \multicolumn{2}{|c|}{$\mathbf{0 - 5} \mathbf{c m}$} & \multicolumn{2}{c|}{$\mathbf{5}-\mathbf{1 0} \mathbf{c m}$} & \multicolumn{1}{c|}{$\mathbf{1 0} \mathbf{~ c m}$} & \multicolumn{2}{c|}{ total } \\
\hline Habitat & $\mathbf{P}$ & $\mathbf{C}$ & $\mathbf{P}$ & $\mathbf{C}$ & $\mathbf{P}$ & $\mathbf{C}$ & $\mathbf{P}$ & $\mathbf{C}$ \\
\hline Collembola & & & & & & & & \\
\hline 1- Thermobia aegyptiaca & 0 & 0 & 0 & $9.4 \pm 0.7$ & 0 & 0 & 0 & 9.4 \\
\hline 2-Isotomina thermophila & 0 & $35.6 \pm 3.6$ & 0 & 0 & 0 & 0 & 0 & 35.6 \\
\hline 3- Isotomina orientalis & $5.4 \pm 0.8$ & $14.4 \pm 1.5$ & 0 & 0 & 0 & 0 & 5.4 & 14.4 \\
\hline 4- Isotoma viridis & $2.2 \pm 0.6$ & $7.4 \pm 0.9$ & 0 & 0 & 0 & 0 & 2.2 & 7.4 \\
\hline 5- Hypogastrura denticulata & 0 & 0 & 0 & $16.6 \pm 1.8$ & 0 & $2.2 \pm 0.4$ & 0 & 18.8 \\
\hline 6-Priosotoma minuta & 0 & 0 & 0 & 0 & 0 & 0 & 0 & 0 \\
\hline 7- Entomobrya dollfusi & $2.2 \pm 0.7$ & $30.4 \pm 2.6$ & 0 & 0 & 0 & 0 & 2.2 & 30.4 \\
\hline Density / sample & 9.8 & 87.8 & 0 & 26 & 0 & 2.2 & & \\
\hline
\end{tabular}


Table (3d). Species richness and densities of collembola (mean \pm SE) at different depths from polluted and control habitats (in autumn).

\begin{tabular}{|l|c|c|c|c|c|c|c|c|}
\hline \multicolumn{1}{|c|}{ Depth } & \multicolumn{2}{|c|}{$\mathbf{0}-\mathbf{5 m}$} & \multicolumn{2}{c|}{$\mathbf{5 - 1 0} \mathbf{~ c m}$} & \multicolumn{2}{c|}{$\mathbf{1 0}-\mathbf{1 5} \mathbf{~ c m}$} & \multicolumn{2}{c|}{ total } \\
\hline \multicolumn{1}{|c|}{ Habitat } & $\mathbf{P}$ & $\mathbf{C}$ & $\mathbf{P}$ & $\mathbf{C}$ & $\mathbf{P}$ & $\mathbf{C}$ & $\mathbf{P}$ & $\mathbf{C}$ \\
\hline 1- Thermobia aegyptiaca & 0 & $1.2 \pm 0.6$ & 0 & $8.2 \pm 1.4$ & 0 & 0 & 0 & 9.4 \\
\hline 2-Isotomina thermophila & 0 & $12.2 \pm 1.6$ & 0 & 0 & 0 & 0 & 0 & 12.2 \\
\hline 3- Isotomina orientalis & $6.8 \pm 0.9$ & $15.6 \pm 2.1$ & $1.8 \pm 0.6$ & $5.4 \pm 0.8$ & 0 & 0 & 8.6 & 21 \\
\hline 4- Isotoma viridis & 0 & $4.4 \pm 0.8$ & 0 & 0 & 0 & 0 & 0 & 4.4 \\
\hline $\begin{array}{l}\text { 5- Hypogastrura } \\
\text { denticulata }\end{array}$ & 0 & $0.8 \pm 0.02$ & 0 & $6.4 \pm 0.4$ & 0 & 0 & 0 & 7.2 \\
\hline 6-Priosotoma minuta & 0 & 0 & 0 & 0 & 0 & 0 & 0 & 0 \\
\hline 7- Entomobrya dollfusi & 0 & $18.8 \pm 2.3$ & 0 & 0 & 0 & 0 & 0 & 18.8 \\
\hline Density / sample & 6.8 & 53 & 1.8 & 20 & 0 & 0 & & \\
\hline
\end{tabular}



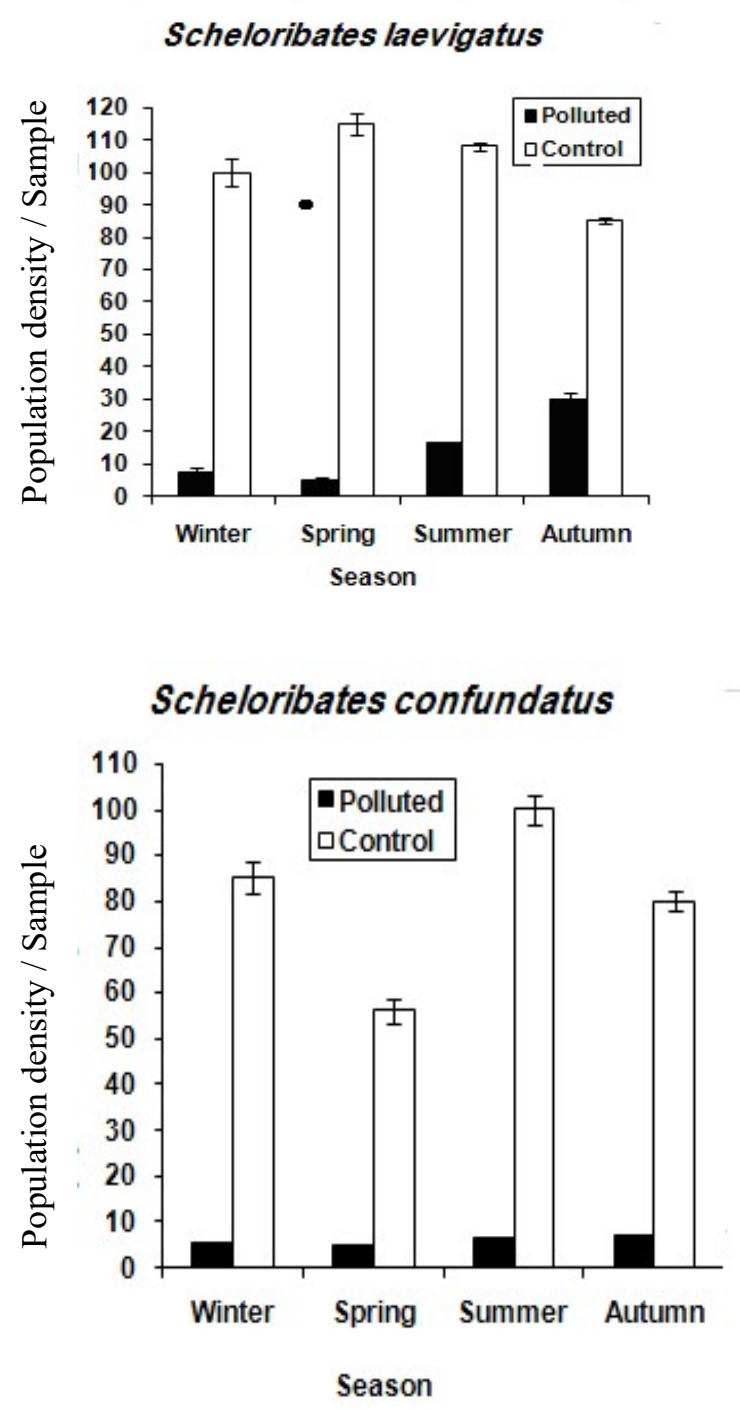
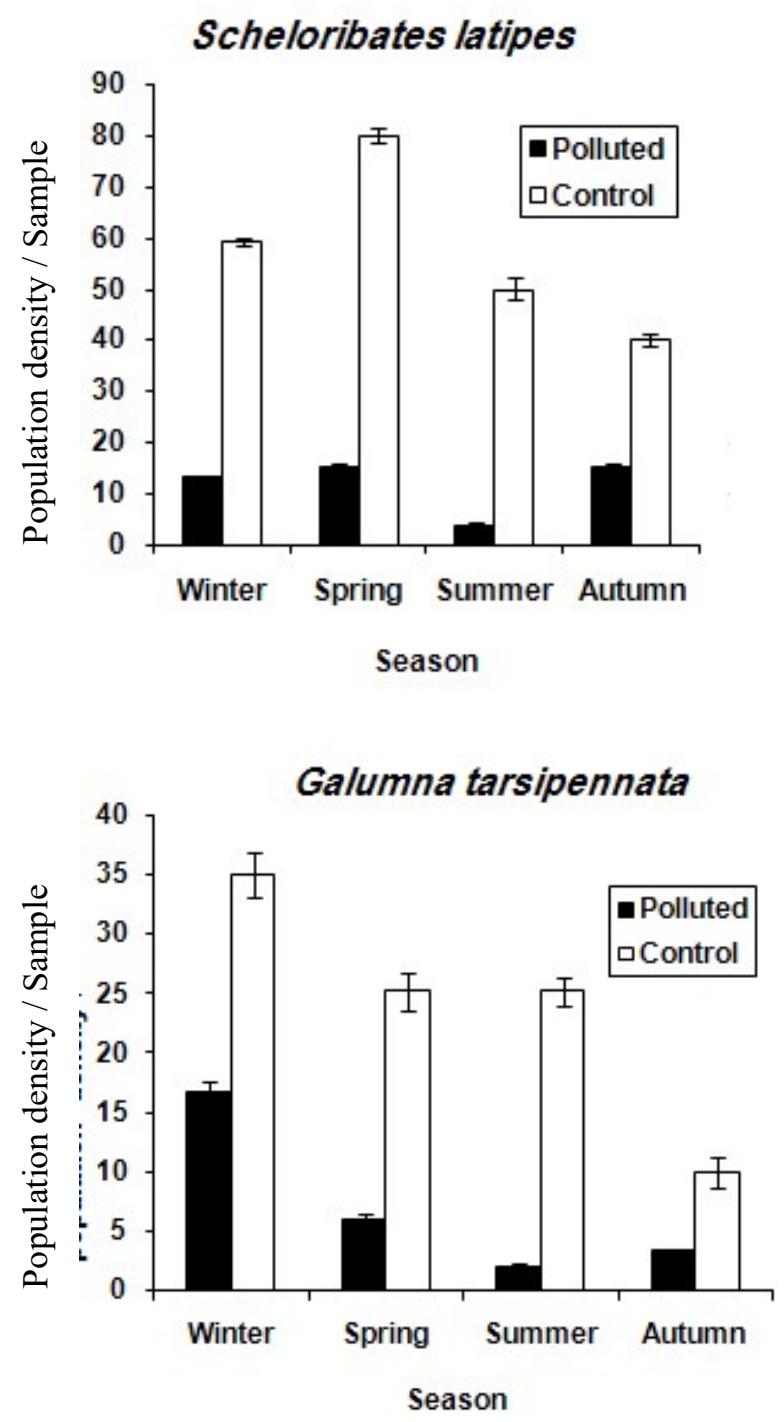

Fig.1. Seasonal population density ( mean $\pm \mathrm{SE}$ ) of four species of Oribatid mites at $0-5 \mathrm{~cm}$ depth from the two studied plots. 

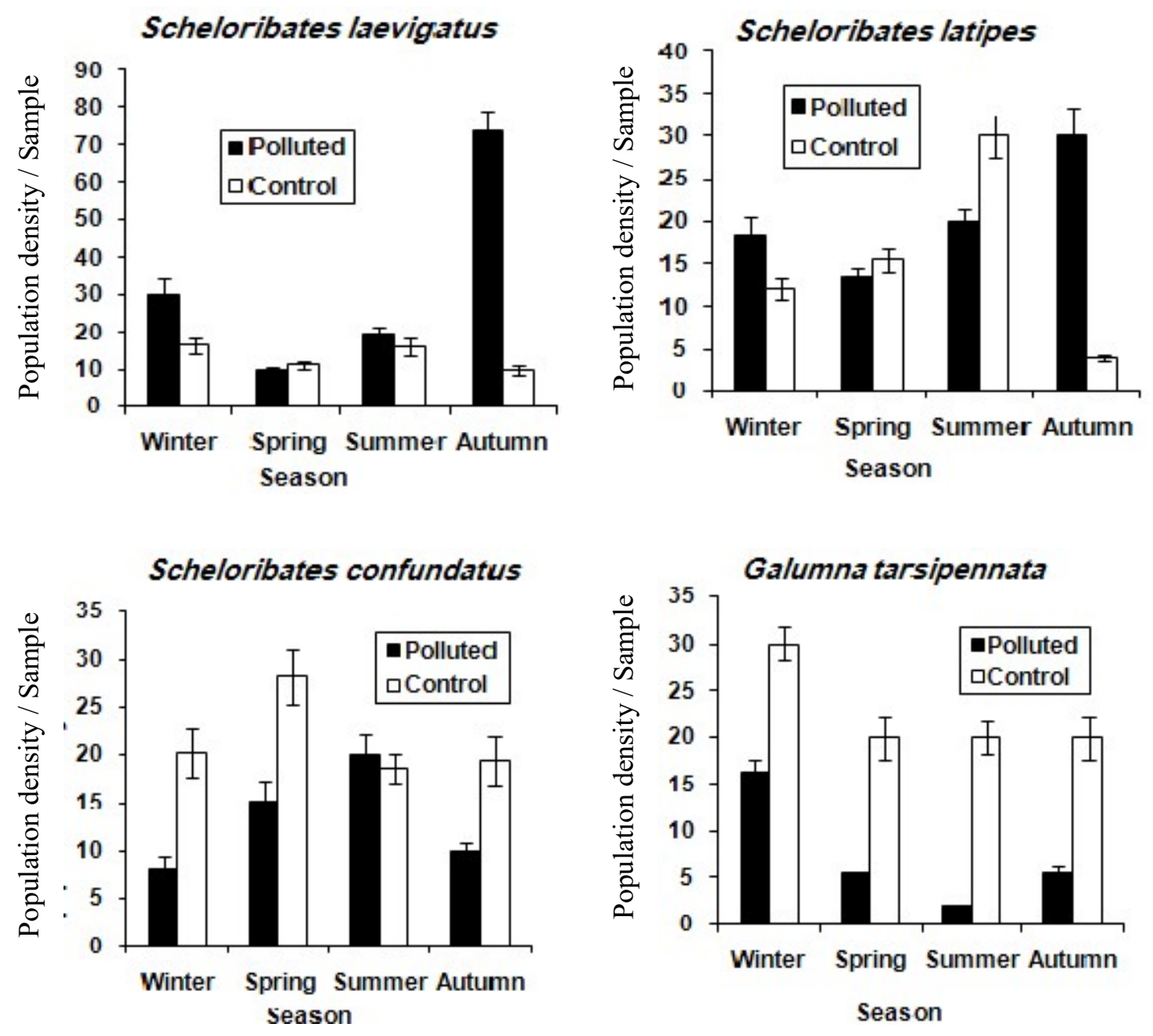

Fig.2. Seasonal population density ( mean \pm SE) of four species of Oribatid mites at $5-10 \mathrm{~cm}$ depth from the two studied plots. 

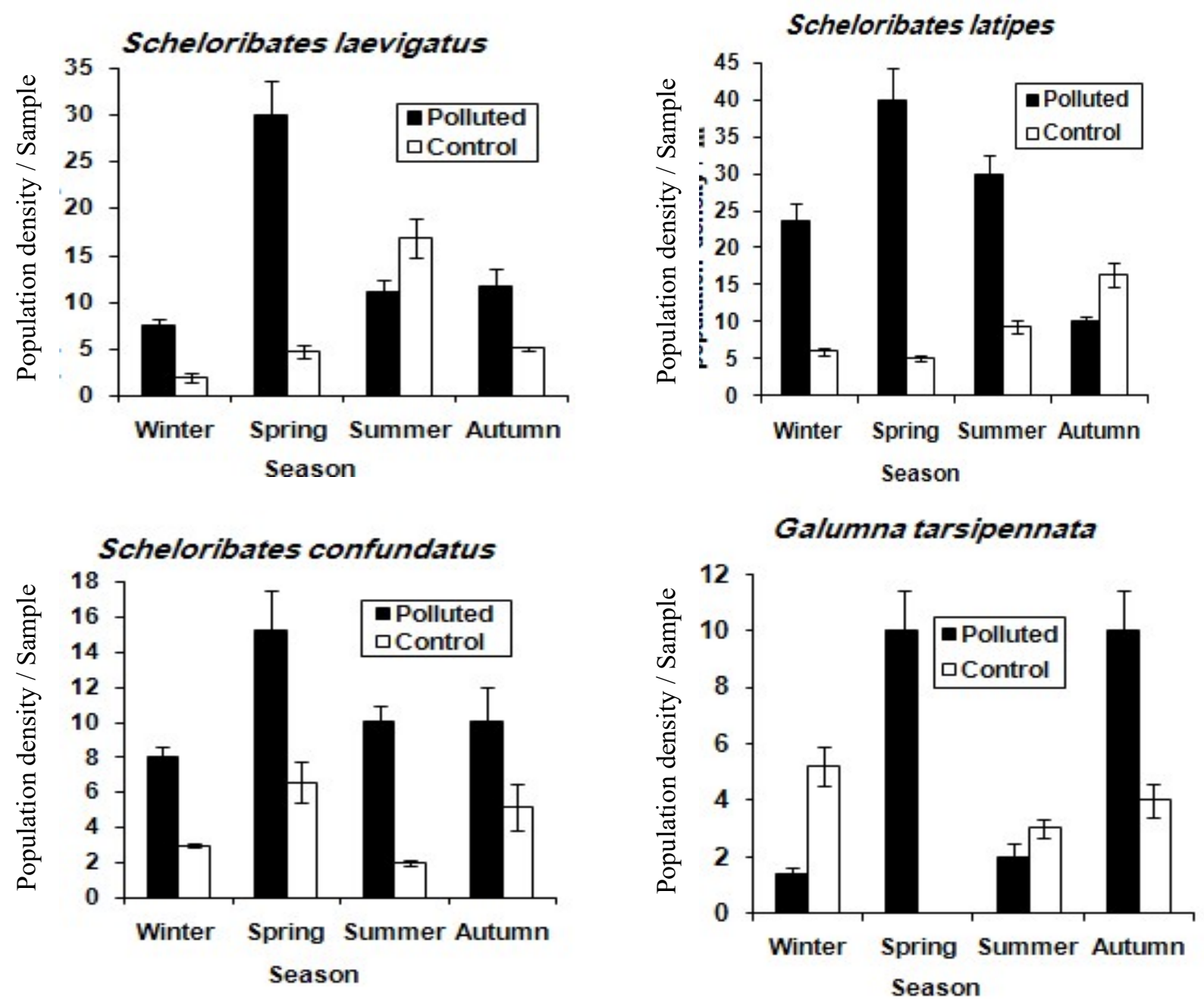

Fig.3. Seasonal population density ( mean $\pm \mathrm{SE}$ ) of four species of Oribatid mites at $10-15 \mathrm{~cm}$ depth from the two studied plots. 


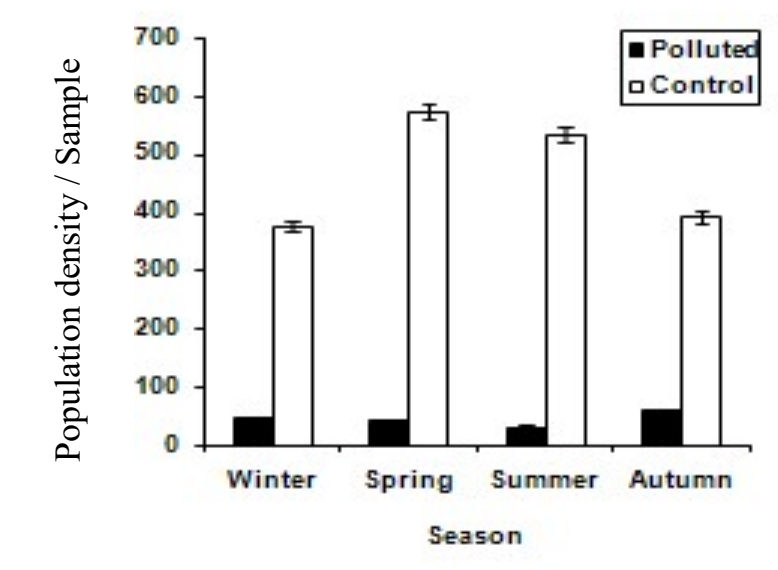

b

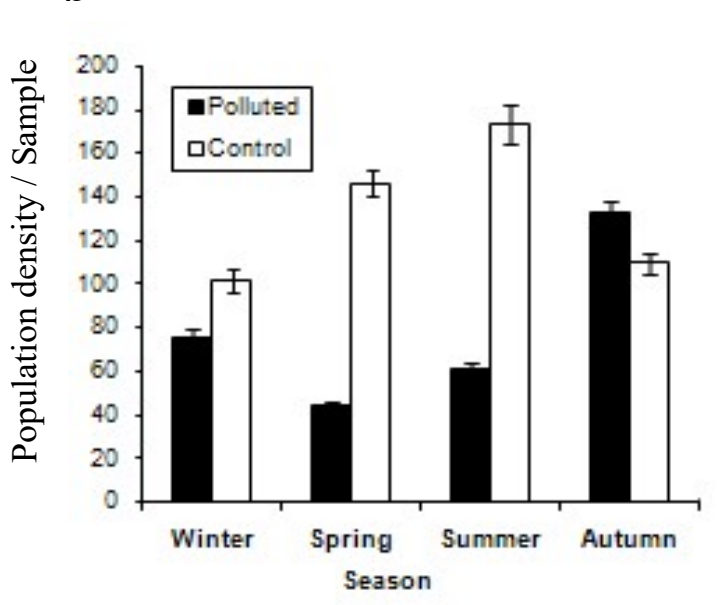

a

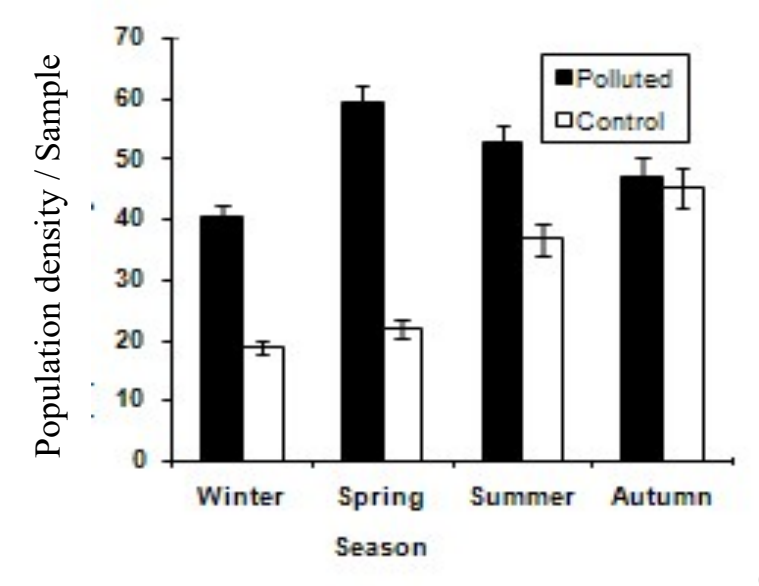

Fig.4. Seasonal population density $($ mean \pm SE) of total Oribatid mites species at Different depths from the two studied plots (a: $0-5 \mathrm{~cm}, \mathrm{~b}: 5-10 \mathrm{~cm}$ and $\mathrm{c}: 10-15 \mathrm{~cm})$. 

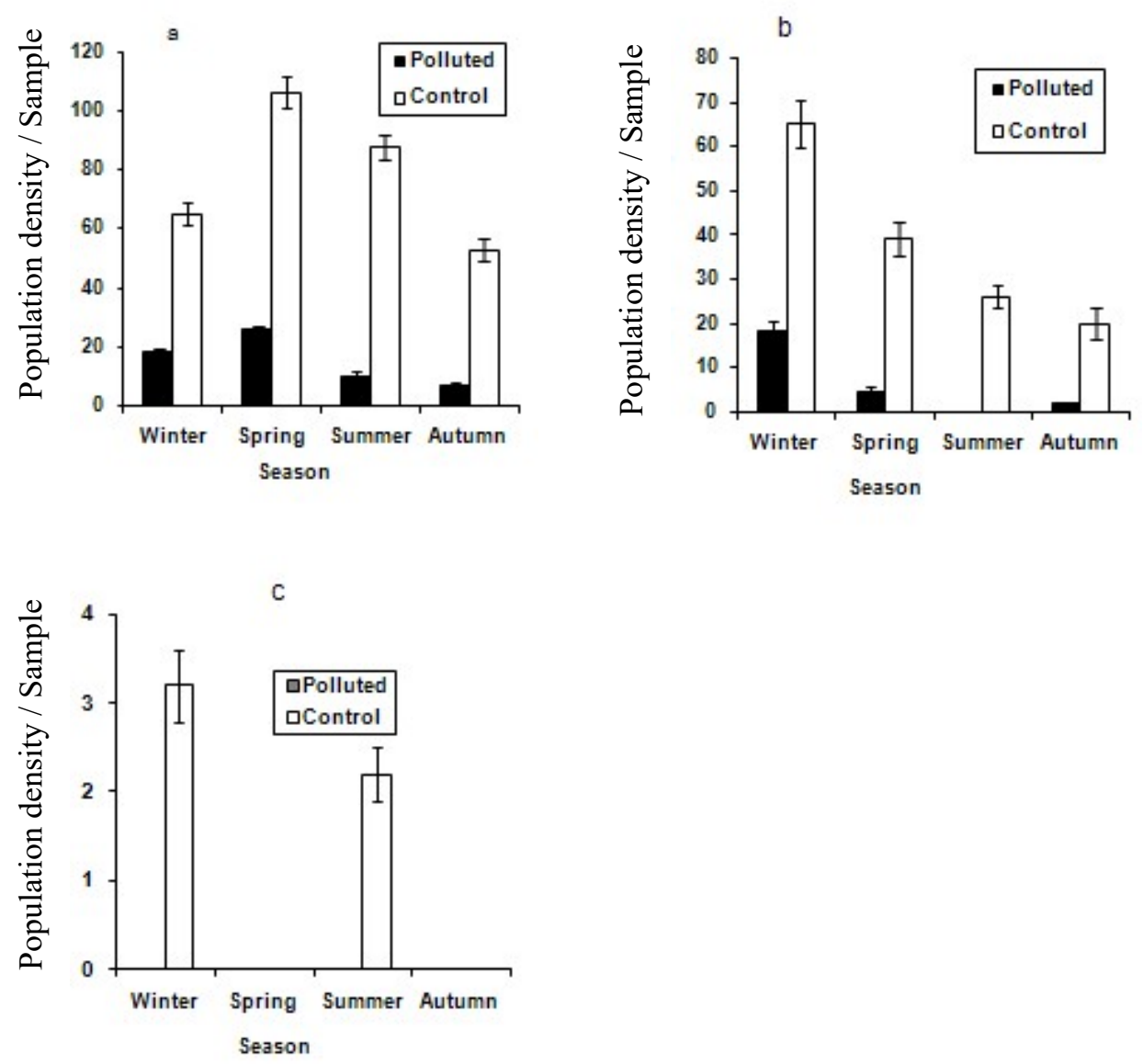

Fig.5. Seasonal population density ( mean \pm SE) of collembolan species at different depths ( a: $0-5 \mathrm{~cm}, \mathrm{~b}: 5-10 \mathrm{~cm}$ and $\mathrm{c}: 10-15 \mathrm{~cm}$ ) collected from the two studied plots.

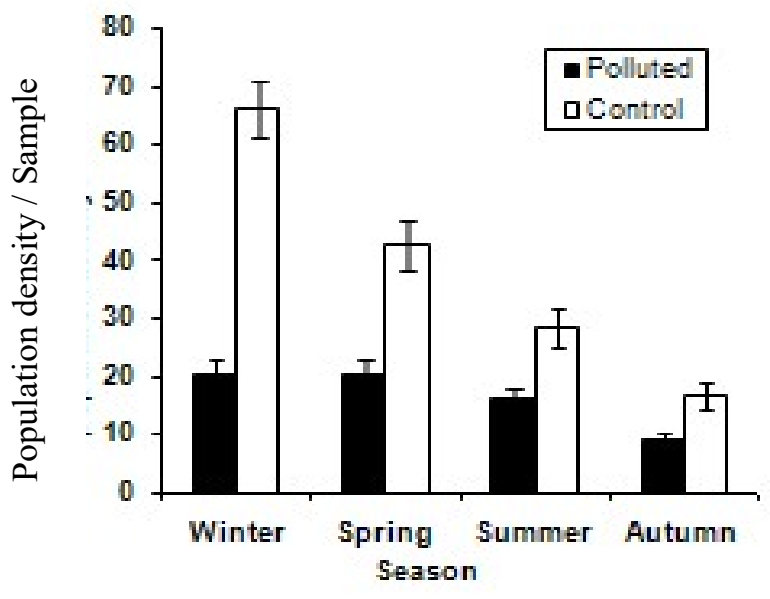

a

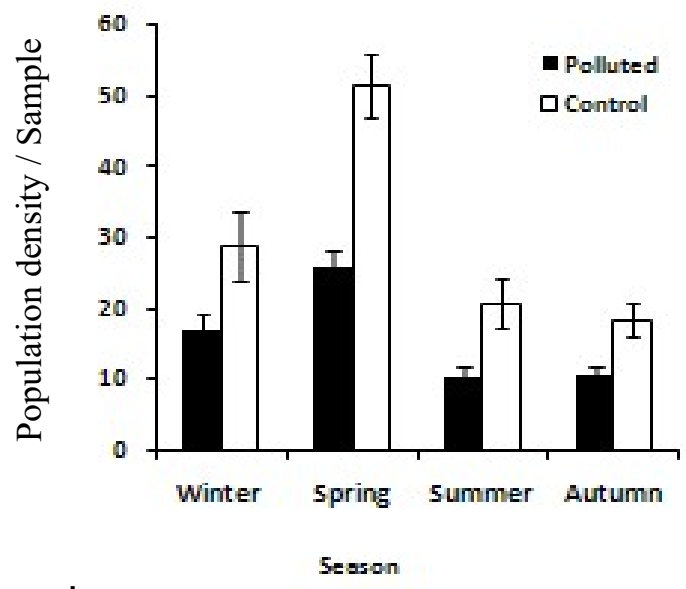

b

Fig.6. Seasonal population density ( mean \pm SE) of mesostigmata species at Different depths (a: $0-5 \mathrm{~cm}$ and b: $5-10 \mathrm{~cm}$ ) from the two studied plots. 


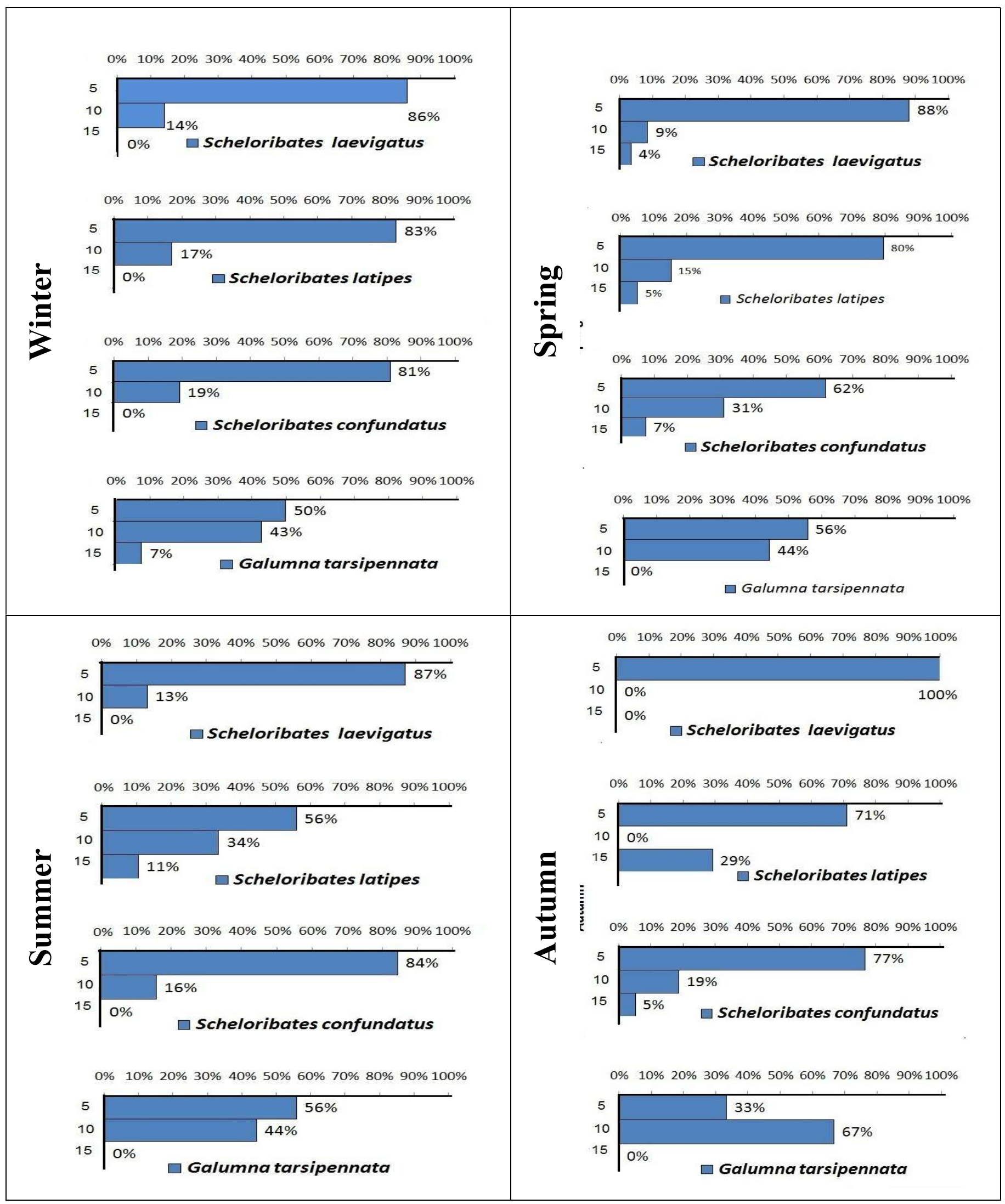

Fig. (7) Vertical distribution of soil mites in samples taken from different depths from control habitats at four seasons of the year. 


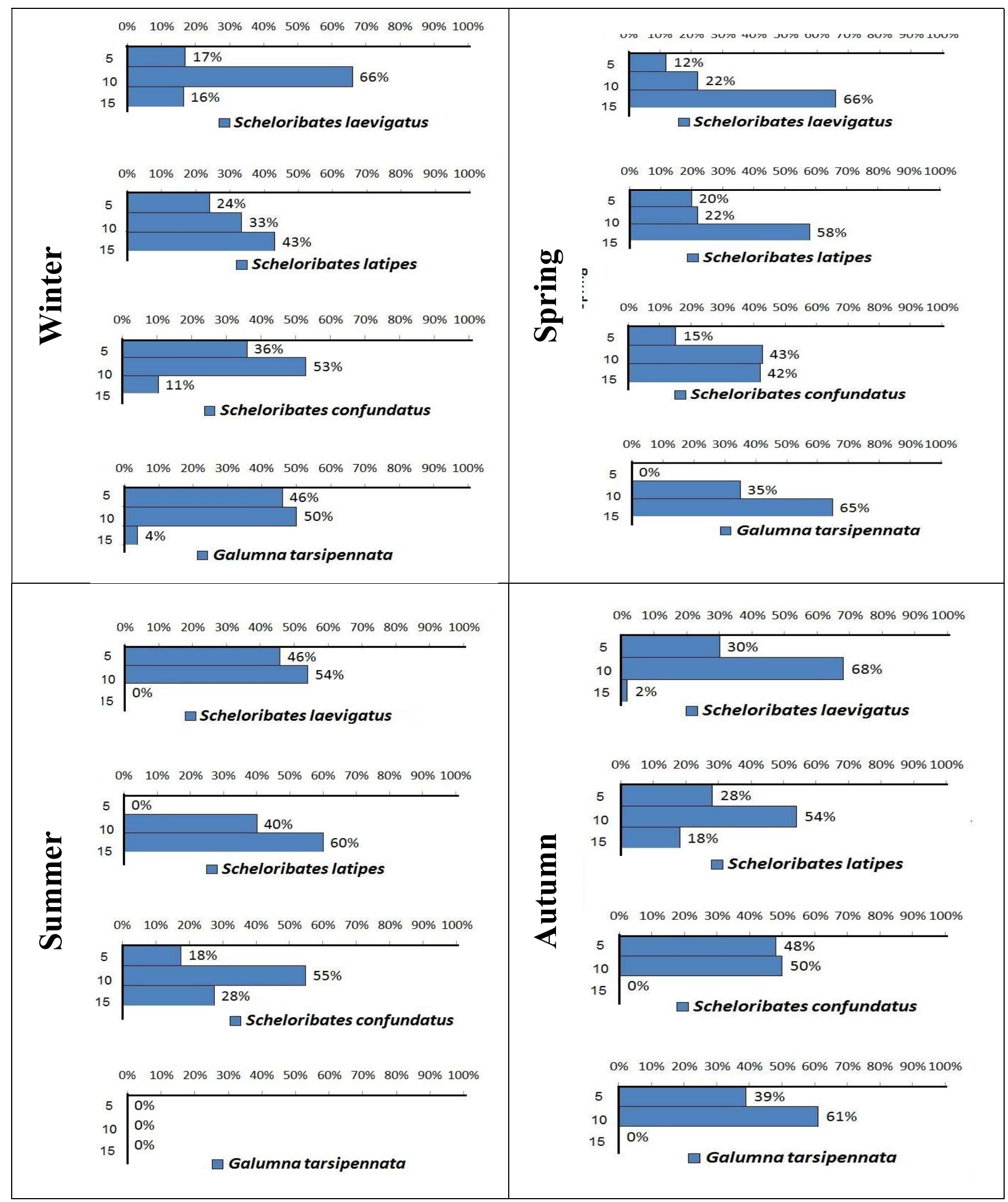

Fig. (8) Vertical distribution of soil mites in samples taken from different depths from polluted habitats at four seasons of the year. 


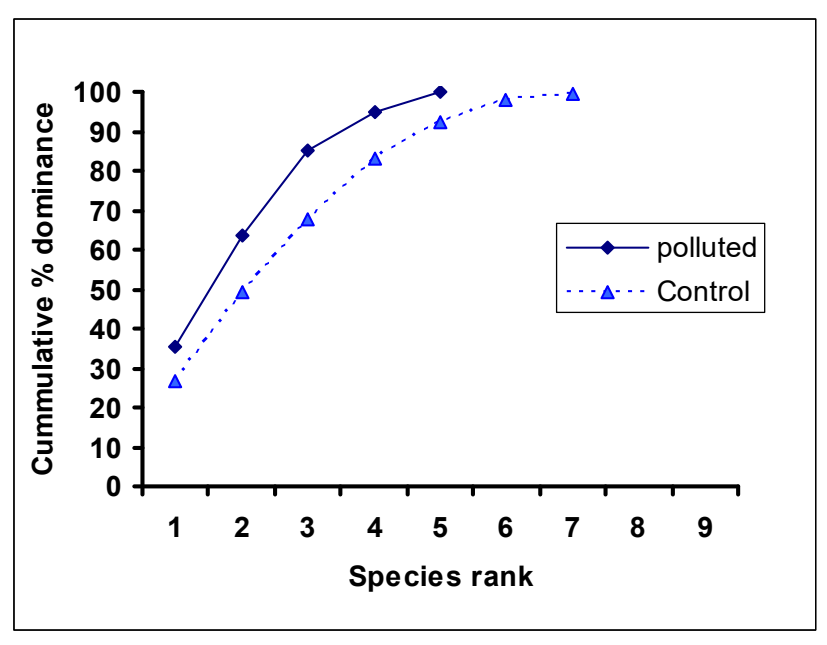

Winter

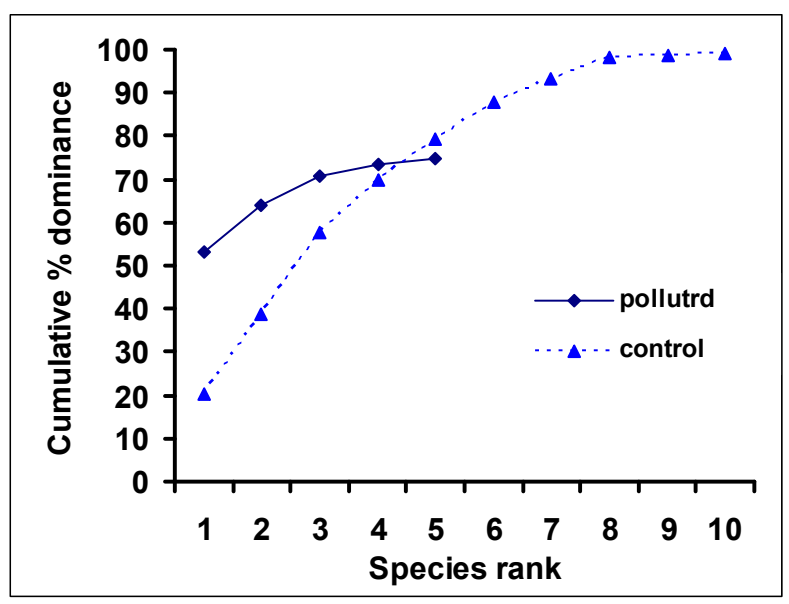

Summer

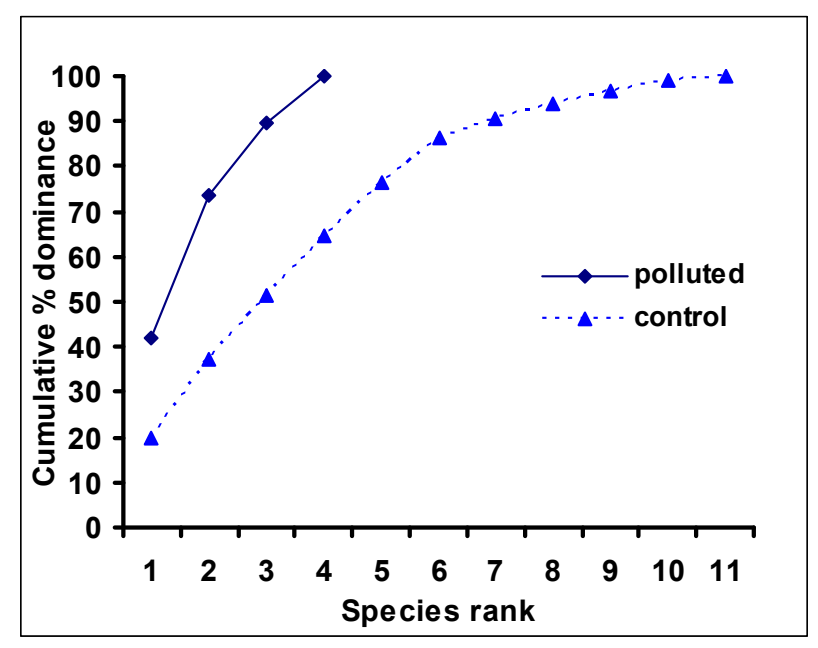

Spring

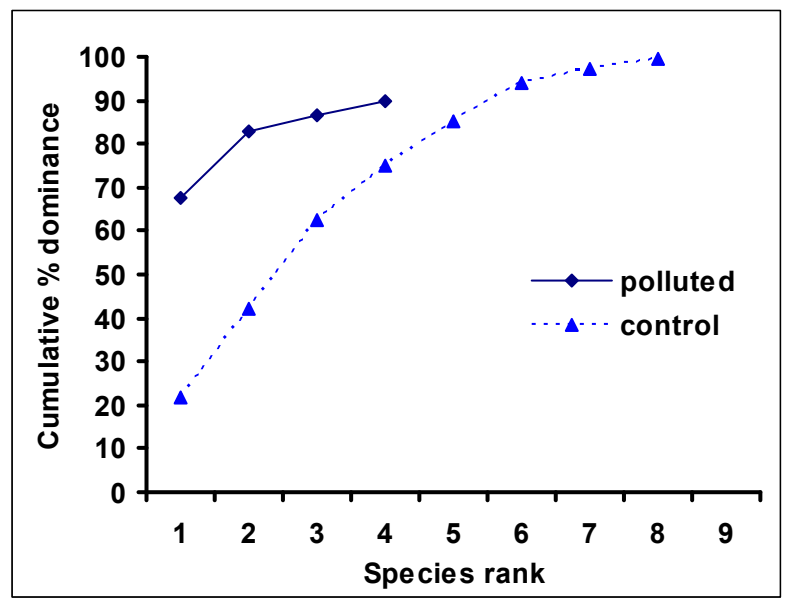

Autumn

Fig. 9. K- dominance curves of Oribatid mite species at $0-5 \mathrm{~cm}$ depth during four seasons in polluted and control habitats. 


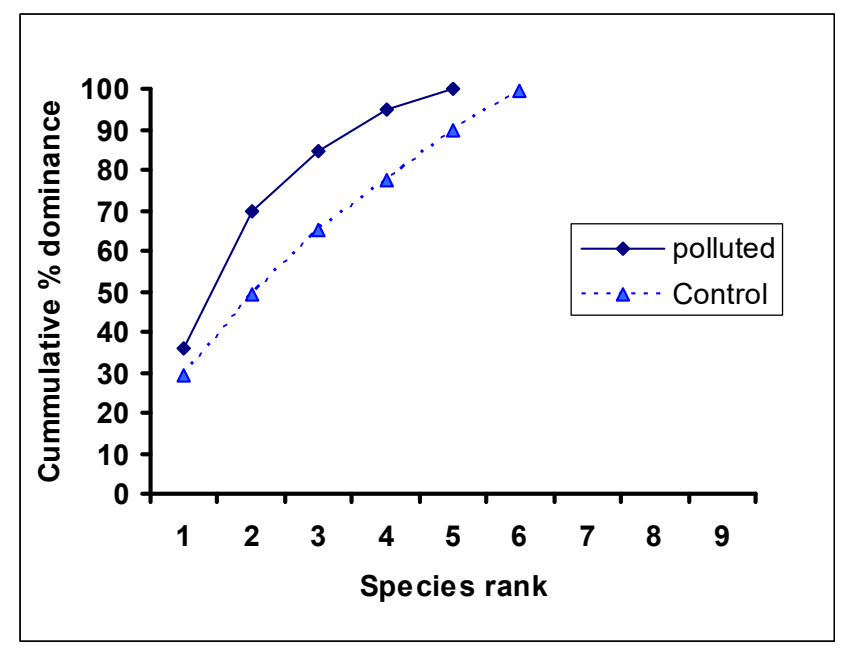

Winter

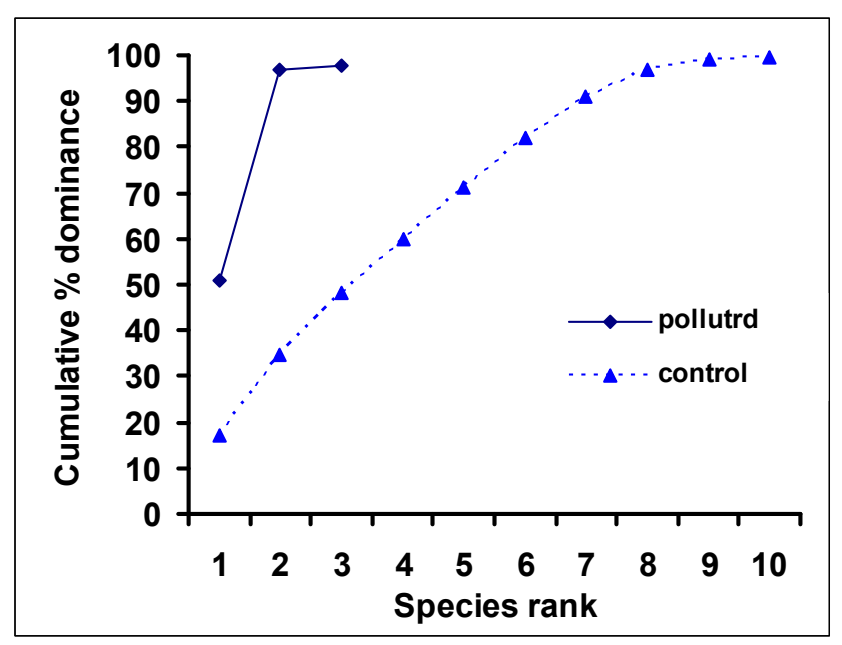

Summer

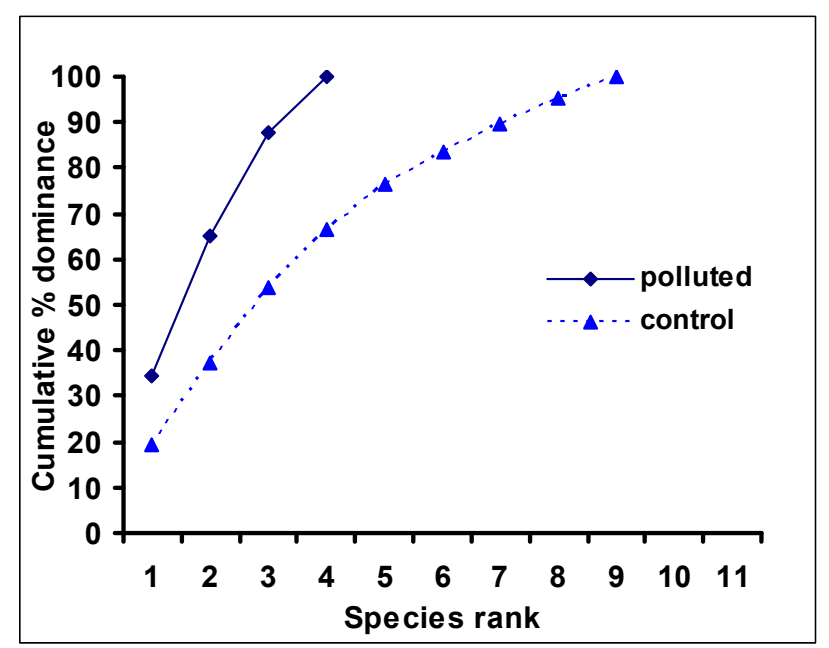

Spring

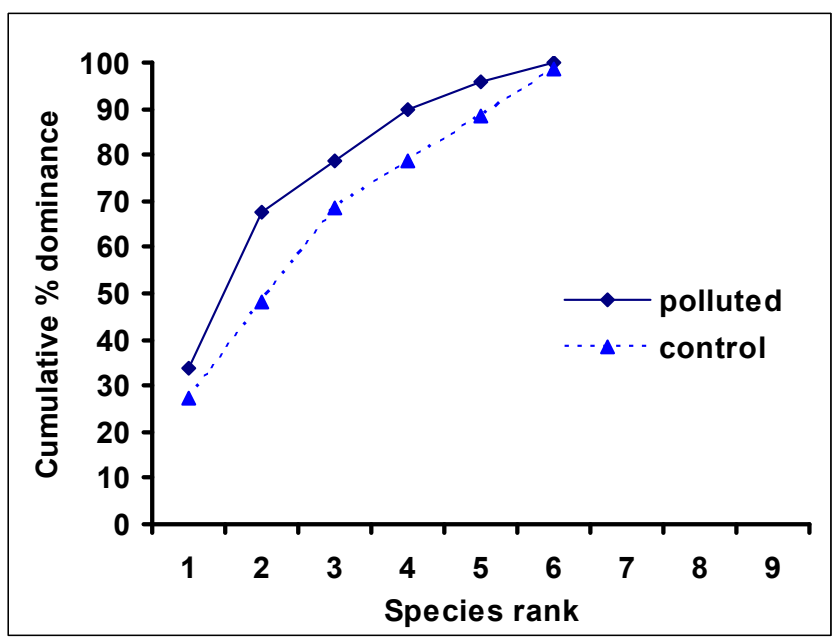

Autumn

Fig.10. K- dominance curves of Oribatid mite species at $5-10 \mathrm{~cm}$ depth during four seasons in polluted and control habitats. 

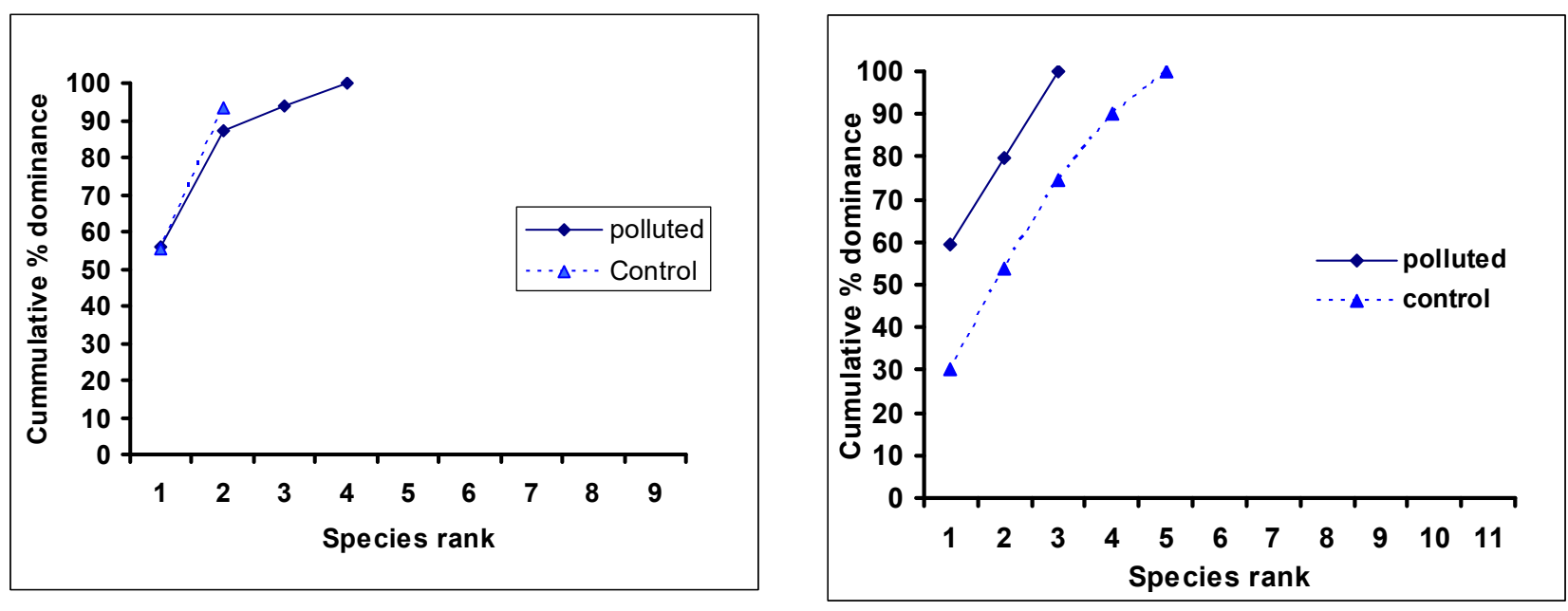

Winter

Spring
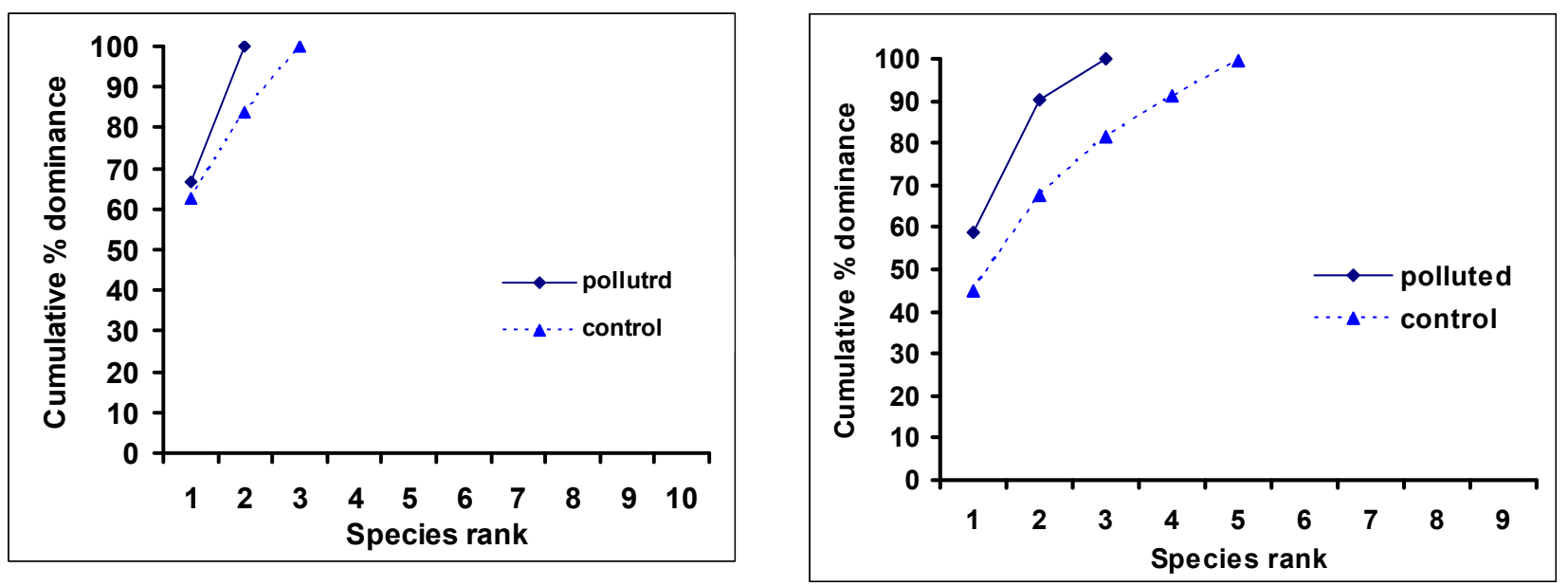

Summer

Autumn

Fig.11. K- dominance curves of Oribatid mite species at $10-15 \mathrm{~cm}$ depth during four seasons in polluted and control habitats. 


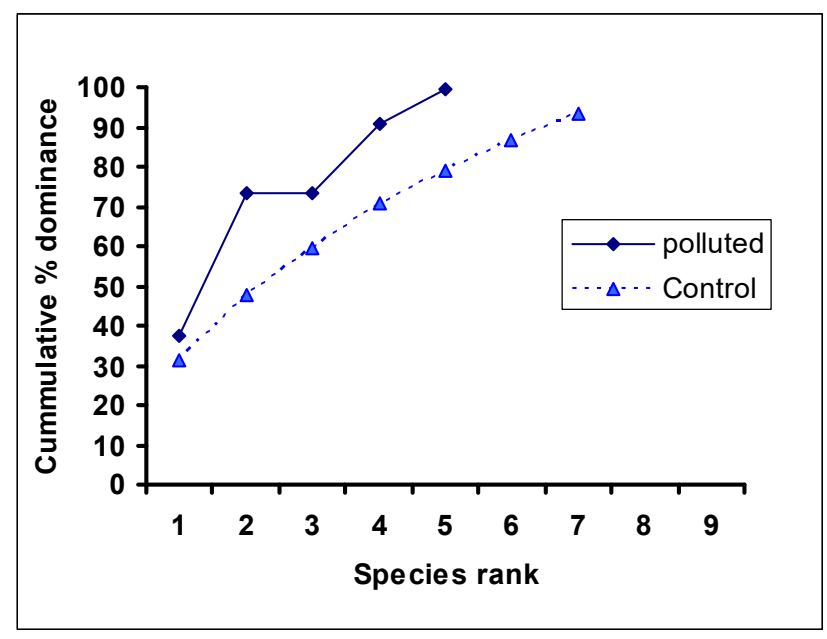

Winter

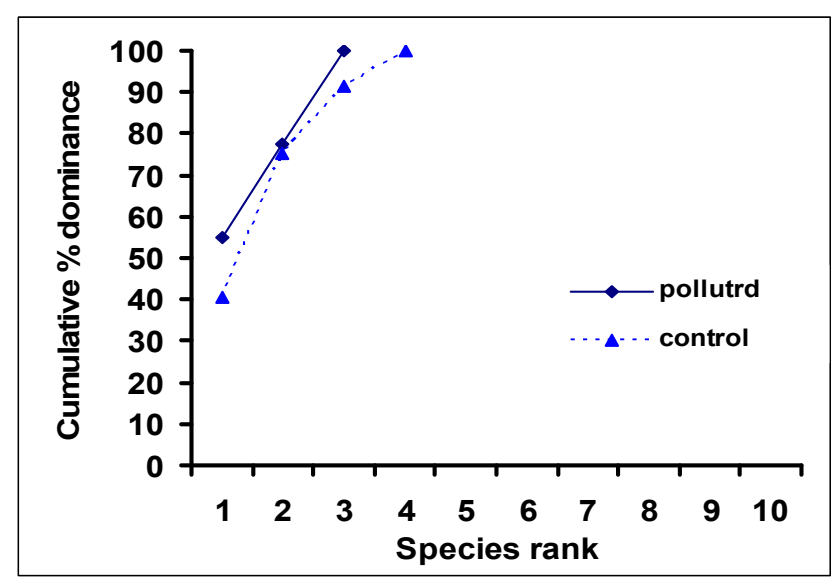

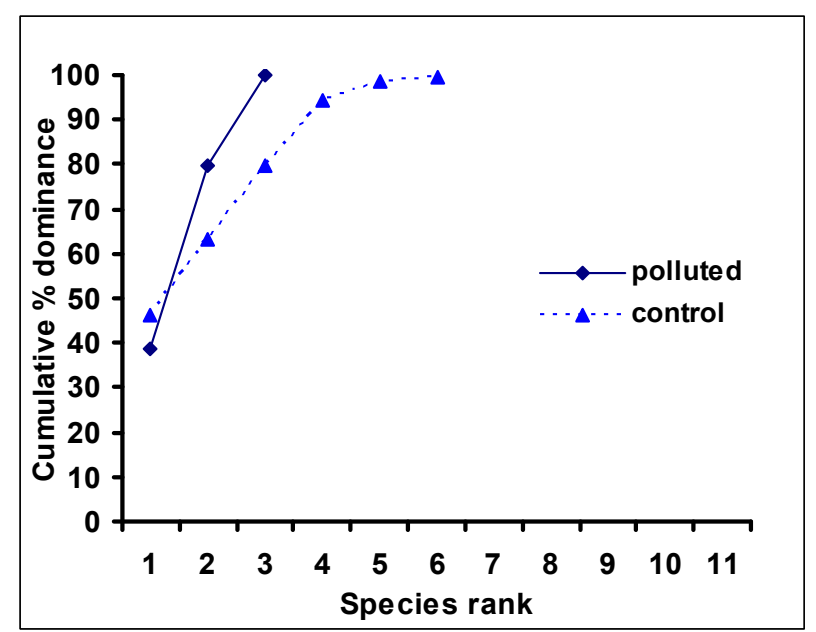

Spring

Summer

Fig. 12. K- Dominance curves of Collembola species at $5-10 \mathrm{~cm}$ depth during three seasons in polluted and control habitats. 